\title{
Synthesis and Pharmacological Evaluation of 3-Amino-1-(5-indanyloxy)- 2-propanol Derivatives as Potent Sodium Channel Blockers for the Treatment of Stroke
}

\author{
Maki Seki, ${ }^{* a}$ Osamu Tsuruta, ${ }^{a}$ Yukio Aoyama, ${ }^{a}$ Aki Soejima,${ }^{b}$ Hiroshi Shimada,${ }^{c}$ and \\ Hikaru Nonaka ${ }^{d}$ \\ ${ }^{a}$ Medicinal Chemistry Research Laboratories I, Mitsubishi Tanabe Pharma Corporation; ${ }^{b}$ Pharmacology Research \\ Laboratories I, Mitsubishi Tanabe Pharma Corporation; ${ }^{c}$ Pharmacology Research Laboratories II, Mitsubishi Tanabe \\ Pharma Corporation; and ${ }^{d}$ Discovery Screening Center, Mitsubishi Tanabe Pharma Corporation; 1000 Kamoshida- \\ cho, Aoba-ku, Yokohama 227-0033, Japan. Received November 24, 2011; accepted January 25, 2012
}

In investigating potent sodium $\left(\mathrm{Na}^{+}\right)$channel blockers for the treatment of ischemic stroke, we synthesized a novel series of 3-amino-1-(5-indanyloxy)-2-propanol derivatives and evaluated their inhibitory effects on neuronal $\mathrm{Na}^{+}$channels. The 3-amino-1-(5-indanyloxy)-2-propanol derivatives exhibited potent blocking activity for $\mathrm{Na}^{+}$channels and a significantly low affinity for dopamine $\mathrm{D}_{2}$ receptors, which demonstrates a minimal clinical risk for extrapyramidal side effects. In particular, compound 4b, a 3-amino1-(5-indanyloxy)-2-propanol derivative bearing a benzimidazole moiety, showed desirable neuroprotective activity in a rat transient middle cerebral artery occlusion model. Furthermore, compound $4 \mathrm{~b}$ displayed a high binding affinity for neurotoxin receptor site 2 of the $\mathrm{Na}^{+}$channels, which suggests that $4 \mathrm{~b}$ would act as a use-dependent $\mathrm{Na}^{+}$channel blocker in sustained depolarization during ischemic stroke.

Key words sodium channel blocker; ischemic stroke; neuroprotection; neurotoxin receptor site 2

Despite their many efforts and the promising neuroprotective action of some drug candidates, such as $N$-methylD-aspartate (NMDA) receptor antagonists, ${ }^{1-3)} \alpha$-amino-5hydroxy-3-methyl-4-isoxazole propionic acid (AMPA) receptor antagonists, ${ }^{4,5)}$ and $\mathrm{Ca}^{2+}$ channel blockers, ${ }^{6)}$ no suitable neuroprotective drug has been approved for the treatment of ischemic stroke. $\mathrm{Na}^{+}$channel blockers inhibit neuronal depolarization, $\mathrm{Na}^{+}$influx, and glutamate release, which reduces $\mathrm{Ca}^{2+}$ influx through $\mathrm{Ca}^{2+}$ and NMDA receptor channels and prevents the reversal of the $\mathrm{Na}^{+} / \mathrm{Ca}^{2+}$ exchanger. ${ }^{7,8)}$

Voltage-gated $\mathrm{Na}^{+}$channels have three distinct functional states: resting, open, and inactivated. ${ }^{9)}$ These functional states determine the permeability of $\mathrm{Na}^{+}$ions. To date, at least eight distinct neurotoxin binding sites and a drug binding site have been identified on $\mathrm{Na}^{+}$channels. These binding sites either affect ion transport directly or modify the gating process. Neurotoxin receptor site 2 binding toxins, such as batrachotoxin (BTX), veratridine, and aconitine,$^{10-12)}$ cause $\mathrm{Na}^{+}$influx and a persistent tendency for depolarization by blocking $\mathrm{Na}^{+}$ channel inactivation and shifting activation to a more negative membrane potential. ${ }^{13,14)}$ Furthermore, compounds that bind to neurotoxin receptor site 2 are thought to block $\mathrm{Na}^{+}$ channels in a use-dependent manner. ${ }^{15-17)}$ The concept of use dependency can be further explained by the modulated receptor hypothesis, ${ }^{18)}$ which proposes that drug binding is tighter to open or inactivated channels than to resting states. These observations suggest that site $2 \mathrm{Na}^{+}$channel blockers may have a minimal effect on normal neuronal signaling but may act more effectively during ischemic conditions, where the membrane potential is persistently depolarized. In contrast, clinical trials of other neuroprotective agents, particularly NMDA receptor antagonists, have been discontinued because of their dose-limiting side effects. ${ }^{19)}$ Thus, $\mathrm{Na}^{+}$channel blockers are promising agents for the treatment of stroke because of their mechanism of action, and they have been in clinical development (Fig. 1). ${ }^{20-23)}$ In this paper, we report the synthesis, modification, and pharmacological evaluation of 3-amino-1-(5indanyloxy)-2-propanol derivatives as $\mathrm{Na}^{+}$channel blockers.

\section{Chemistry}

We previously discovered compound $\mathbf{1}$, which had a potent binding affinity for the BTX binding site on $\mathrm{Na}^{+}$channels (Fig. 2), using high-throughput screening (HTS). However, this compound also showed a high affinity for dopamine $\mathrm{D}_{2}$ receptors, which indicates a high clinical risk for extrapyramidal side effects. ${ }^{24)}$ Thus, we initiated a search for $\mathrm{Na}^{+}$channel blockers with high in vivo neuroprotective activity and a low affinity for dopamine $D_{2}$ receptors. SUN N8075 bearing a 1-phenoxy-3-piperazinyl-2-propanol moiety is a $\mathrm{Na}^{+}$channel blocker that lacks binding affinity to dopamine $\mathrm{D}_{2}$ receptors. ${ }^{23)}$ Compound 1 has a 3-amino-1-(5-indanyloxy)-2-propanol moi-

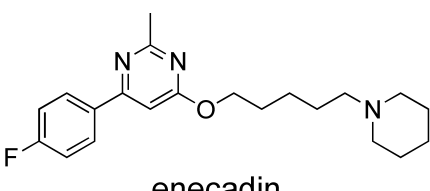

enecadin
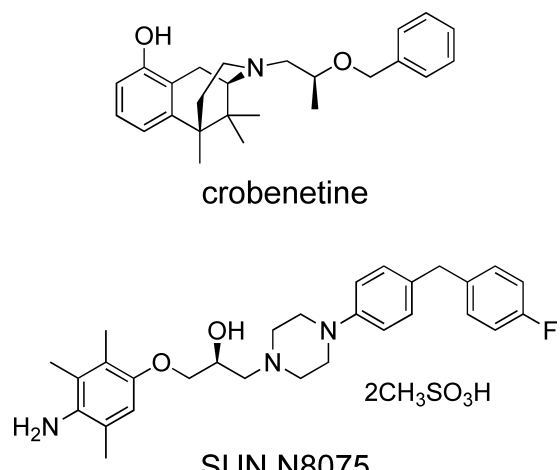

SUN N8075

Fig. 1. Chemical Structure of $\mathrm{Na}^{+}$Channel Blockers 
ety as a common structure with SUN N8075; therefore, we identified the 3-amino-1-(5-indanyloxy)-2-propanol moiety as a $\mathrm{Na}^{+}$channel blocker pharmacophore and attempted to modify the amine moiety of compound $\mathbf{1}$.

Syntheses of the biarylpiperidines $(\mathbf{8 c}, \mathbf{1 0 a}, \mathbf{c})$ and biarylpiperazines $(\mathbf{6}, \mathbf{1 4 a}-\mathbf{c})$ are shown in Chart 1 . Coupling compound $\mathbf{5}$ with 2,2'-dichloroethylamine hydrochloride yielded compound $\mathbf{6}$. Compounds $\mathbf{8 a}, \mathbf{8 b}$, and $\mathbf{8 d}$ were synthesized from piperidones $\mathbf{7 a}$ or $\mathbf{7 b}$ by the Grignard reaction. ${ }^{25)}$ Dehydration of the hydroxypiperidines $8 \mathbf{a}$ and $\mathbf{8 d}$ with trifluoroacetic acid (TFA) afforded compounds 9a and 9b,
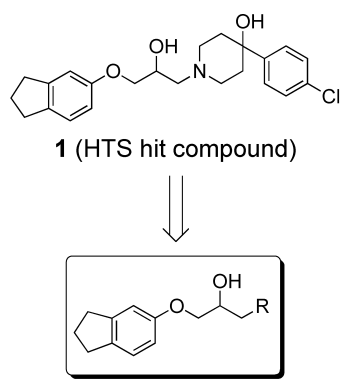

$\mathrm{R}$ :
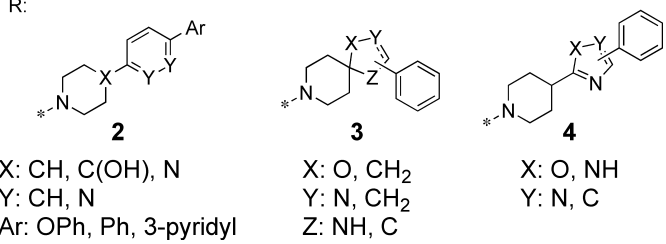

$\mathrm{X}: \mathrm{CH}, \mathrm{C}(\mathrm{OH}), \mathrm{N}$

$\mathrm{Y}: \mathrm{CH}, \mathrm{N}$

Ar: OPh, Ph, 3-pyridyl

$\mathrm{Z}: \mathrm{NH}, \mathrm{C}$

Fig. 2. Synthetic Strategy from HTS Hit Compound $\mathbf{1}$

respectively, and the cleavage of the ethyl carbamate group of compound $\mathbf{8 b}$ afforded compound $\mathbf{8 c}$. Compound 9a was hydrogenated to yield compound 10a. Compound 9b was converted to the biarylpiperidine $\mathbf{1 0 b}$ in a four-step sequence, including (i) the protection of the piperidine moiety by a tert-

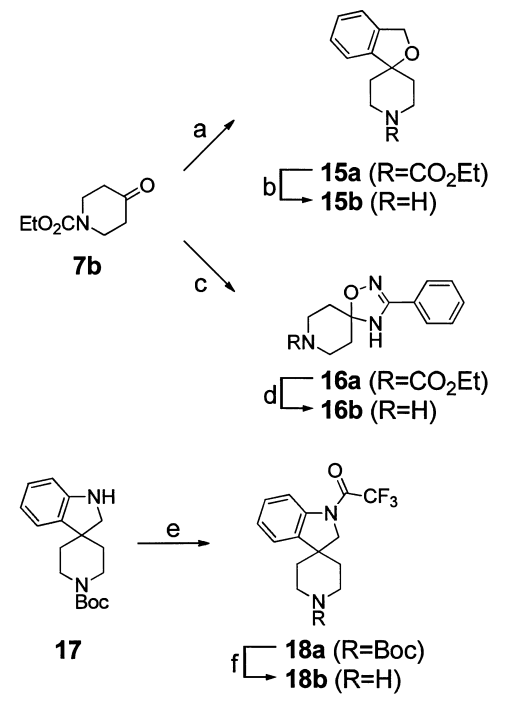

Reagents and conditions: (a) (i) 2-bromobenzyl alcohol, $n$-BuLi, $\mathrm{THF},-78^{\circ} \mathrm{C}$; (ii) $\mathrm{TsCl}$, pyridine, $\mathrm{CH}_{2} \mathrm{Cl}_{2}, \mathrm{rt}$; (b) $5 \mathrm{M}$ aqueous $\mathrm{NaOH}$, $\mathrm{EtOH}$, reflux; (c) benzamidoxime, $\mathrm{TsOH} \cdot \mathrm{H}_{2} \mathrm{O}$, toluene, reflux; (d) $\mathrm{Ba}(\mathrm{OH})_{2} \cdot 8 \mathrm{H}_{2} \mathrm{O}, \mathrm{EtOH} / \mathrm{H}_{2} \mathrm{O}$, reflux; (e) trifluoroacetic anhydride, $\mathrm{Et}_{3} \mathrm{~N}, \mathrm{CH}_{2} \mathrm{Cl}_{2}, 0^{\circ} \mathrm{C}$; (f) $4 \mathrm{M} \mathrm{HCl} / \mathrm{EtOAt}$ EtOAc, rt.

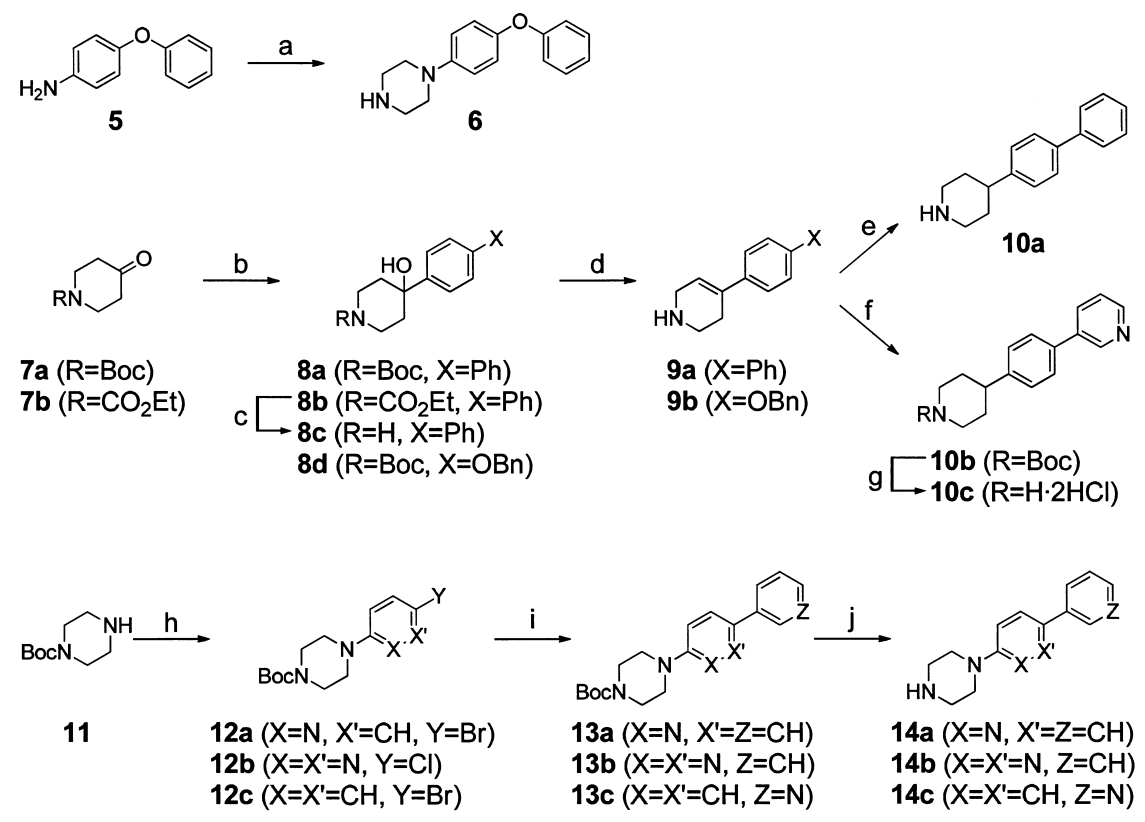

Reagents and conditions: (a) 2,2'-dichloroethylamine hydrochloride, $200^{\circ} \mathrm{C}$; (b) 4-biphenyl magnesium bromide (for 8a and 8b) or 4-(benzyloxy)bromobenzene, $\mathrm{Mg}$ (for 8d), THF, $0^{\circ} \mathrm{C}$; (c) $5 \mathrm{M}$ aqueous $\mathrm{NaOH}$, EtOH, reflux; (d) TFA, $\mathrm{CH}_{2} \mathrm{Cl}_{2}, 0^{\circ} \mathrm{C}$ to rt; (e) $\mathrm{H}_{2}, \mathrm{Pd} / \mathrm{C}, \mathrm{MeOH} / \mathrm{H}_{2} \mathrm{O}, 60^{\circ} \mathrm{C}$; (f) (i) (Boc) $)_{2} \mathrm{O}, \mathrm{THF}$, reflux; (ii) $\mathrm{H}_{2}, \mathrm{Pd} / \mathrm{C}, \mathrm{EtOH} / \mathrm{THF}, 50^{\circ} \mathrm{C}$; (iii) trifluoromethanesulfonic anhydride, pyridine, $\mathrm{CH}_{2} \mathrm{Cl}_{2}, 0^{\circ} \mathrm{C}$ to $\mathrm{rt}$; (iv) pyridine-3-boronic acid, $\mathrm{Pd}\left(\mathrm{PPh}_{3}\right)_{4}, 2 \mathrm{M}$ aqueous $\mathrm{Na}_{2} \mathrm{CO}_{3}$, toluene/EtOH, $100^{\circ} \mathrm{C}$; $(\mathrm{g}) 2 \mathrm{M} \mathrm{HCl} / \mathrm{MeOH}, \mathrm{EtOAc}$, rt; (h) 2,5-dibromopyridine (for 12a) or 3,6-dichloropyridazine (for 12b), $N, N$-diisopropylethylamine, $N$ methylpyrrolidone, $120^{\circ} \mathrm{C}$; (i) phenylboronic acid (for 13a and 13b) or pyridine-3-boronic acid (for 13c), $\mathrm{Pd}\left(\mathrm{PPh}_{3}\right)_{4}, 2 \mathrm{M}$ aqueous $\mathrm{Na}_{2} \mathrm{CO}_{3}$, dioxane, $100^{\circ} \mathrm{C}$; (j) TFA, $\mathrm{CH}_{2} \mathrm{Cl}_{2}, 0^{\circ} \mathrm{C}$ to rt. 
butyl carbamate (Boc) group, (ii) the reduction of the double bond and deprotection of the benzyl group, (iii) the conversion of the resulting phenol group to a triflate group, and (iv) coupling with pyridine-3-boronic acid. Deprotection of the Boc group of compound $10 \mathrm{~b}$ yielded compound 10c. Compounds 12a and 12b were obtained from the corresponding heteroaromatic halides by a nucleophilic substitution reaction with piperazine 11. The Suzuki-Miyaura coupling of compounds 12a-c with the corresponding boronic acids, ${ }^{26,27)}$ followed by deprotection of the Boc group afforded biarylpiperazines $14 a-c$.

The spiro-piperidines $\mathbf{1 5 b}$ and $\mathbf{1 6 b}$ were prepared from the piperidone $\mathbf{7 b}$ as illustrated in Chart 2. Compound $\mathbf{1 5 b}$ was synthesized according to the procedure of Kubota et al. ${ }^{28)}$ Condensation of $\mathbf{7 b}$ with benzamidoxime in the presence of $p$ toluenesulfonic acid ( $\mathrm{TsOH})$ produced compound 16a, which was then treated with barium hydroxide ${ }^{29}$ to give compound 16b. Protection of commercially available $\mathbf{1 7}$ by a trifluoroacetyl group, followed by the cleavage of the Boc group of 18a
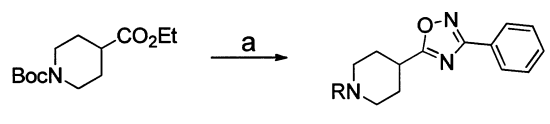

19
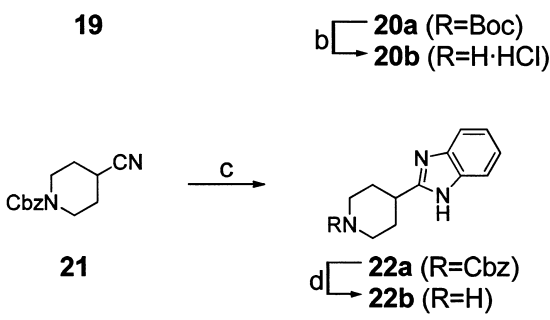

Reagents and conditions: (a) benzamidoxime, NaOEt, $\mathrm{THF} / \mathrm{EtOH}, 70^{\circ} \mathrm{C}$; (b) $4 \mathrm{M} \mathrm{HCl} / \mathrm{EtOAc}$, EtOAc, rt; (c) (i) EtOH, acetyl chloride, $\mathrm{CH}_{2} \mathrm{Cl}_{2}, 0^{\circ} \mathrm{C}$ to $\mathrm{rt}$; (ii) $o$ phenylenediamine, EtOH, reflux; (d) $\mathrm{H}_{2}, \mathrm{Pd} / \mathrm{C}, \mathrm{MeOH}$, rt.

Chart 3 yielded compound $\mathbf{1 8 b}$.

Chart 3 shows the syntheses of the heteroarylpiperidines $\mathbf{2 0 b}$ and $\mathbf{2 2 b}$. The oxadiazole 20a was prepared by the cyclization of compound 19 with benzamidoxime under basic conditions, ${ }^{30)}$ and then, the deprotection of the Boc group of 20a afforded compound 20b. The benzimidazole 22a was synthesized by the condensation reaction of phenylenediamine and imido ester hydrochloride, which was obtained from the nitrile $\mathbf{2 1},{ }^{31)}$ and then, the deprotection of the benzyl carbamate $(\mathrm{Cbz})$ group yielded compound $\mathbf{2 2 b}$.

Compounds $\mathbf{2 a}-\mathbf{g}, \mathbf{3 a}-\mathbf{c}$, and $\mathbf{4 a}-\mathbf{b}$ were synthesized as illustrated in Chart 4. Compound $\mathbf{2 4}$ was obtained from 5-indanol (23) and epichlorohydrin by a nucleophilic substitution reaction. Next, the epoxide 24 was coupled with a corresponding piperidine (8c, 10a, c, 15b, 16b, 18b, 20b, or 22b) or piperazine ( 6 or $14 \mathbf{a}-\mathbf{c})$, followed by treatment with hydrochloric acid to give the piperidine derivatives $(\mathbf{2} \mathbf{b}-\mathbf{d}, \mathbf{3 a}-\mathbf{c}, \mathbf{4 a}, \mathbf{b})$ or piperazine derivatives $(\mathbf{2} \mathbf{a}, \mathbf{e}-\mathbf{g})$, respectively.

\section{Results and Discussion}

The effect of the synthesized compounds on $\mathrm{Na}^{+}$channels was evaluated in rat cerebrocortical synaptosomes. The inhibitory activity on veratridine-induced depolarization was measured using voltage-sensitive dye rhodamine $6 \mathrm{G} .{ }^{32)}$ The binding affinity for dopamine $\mathrm{D}_{2}$ receptors was assessed in rat striatum membranes using $\left[{ }^{3} \mathrm{H}\right]$-spiperone as a radioligand.

As shown in Table 1, most of the biarylpiperidines and biarylpiperazines $(\mathbf{2 a}-\mathbf{g})$ showed inhibitory activity for $\mathrm{Na}^{+}$ channels comparable to compound 1. Aryl- or heteroarylsubstituted piperidines or piperazines, such as haloperidol and risperidone, have been reported to represent one of the largest categories of chemical structures with dopaminergic properties. ${ }^{33)}$ Surprisingly, compounds $\mathbf{2 a}-\mathbf{g}$ showed no binding affinity for the dopamine $\mathrm{D}_{2}$ receptors $\left(K_{\mathrm{i}}>10 \mu \mathrm{M}\right)$, although they would be classified as a similar chemical class. These results suggest that the terminal aromatic ring of the biarylpiperidines and biarylpiperazines may interfere with binding to the dopa-

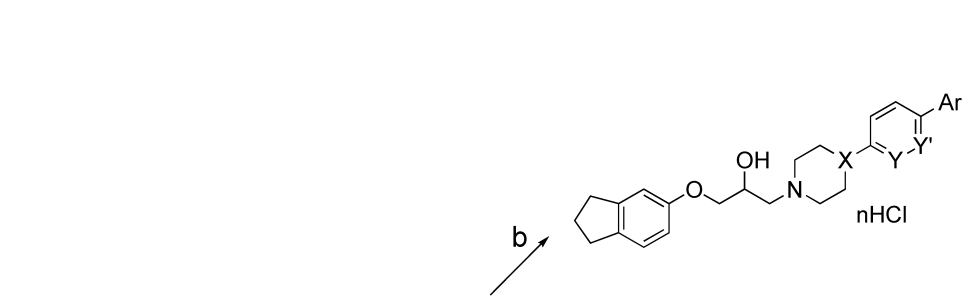

2a: $X=\mathrm{N}, Y-Y^{\prime}=\mathrm{CH}-\mathrm{CH}, \mathrm{Ar}=\mathrm{OPh}, \mathrm{n}=1$

2b: $X=\mathrm{C}(\mathrm{OH}), \mathrm{Y}-\mathrm{Y}^{\prime}=\mathrm{CH}-\mathrm{CH}, \mathrm{Ar}=\mathrm{Ph}, \mathrm{n}=1$

2c: $X=C H, Y-Y^{\prime}=\mathrm{CH}-\mathrm{CH}, \mathrm{Ar}=\mathrm{Ph}, \mathrm{n}=1$

2d: $X=\mathrm{CH}, Y-Y^{\prime}=\mathrm{CH}-\mathrm{CH}, \mathrm{Ar}=3-p y r i d y l, n=2$

2e: $X=\mathrm{N}, Y-Y^{\prime}=\mathrm{N}-\mathrm{CH}, \mathrm{Ar}=\mathrm{Ph}, \mathrm{n}=2$

2f: $X=N, Y-Y^{\prime}=N-N, A r=P h, n=1$

2g: $X=\mathrm{N}, \mathrm{Y}-\mathrm{Y}^{\prime}=\mathrm{CH}-\mathrm{CH}, \mathrm{Ar}=3-\mathrm{pyridyl}, \mathrm{n}=2$

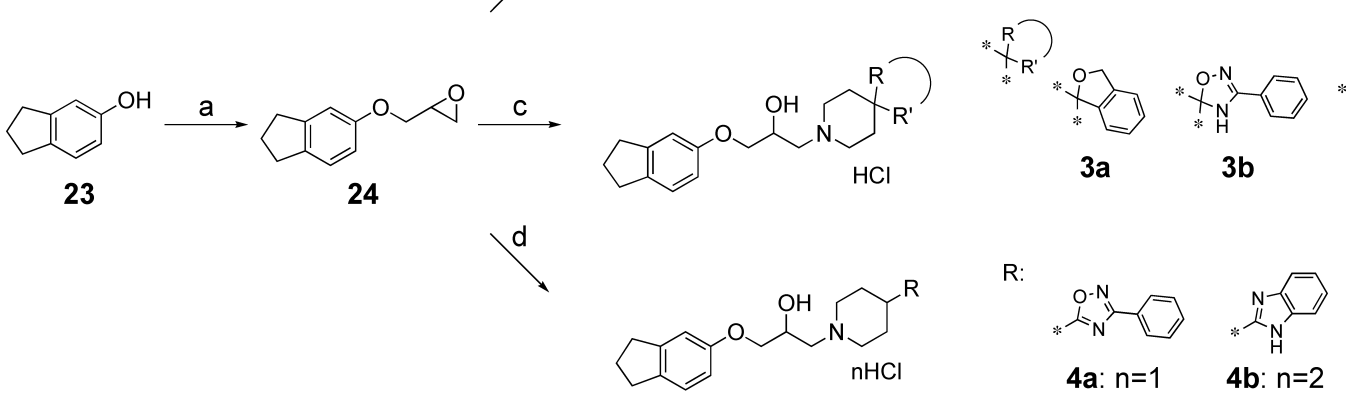

Reagents and conditions: (a) (i) $\mathrm{NaH}, \mathrm{DMF}, 0^{\circ} \mathrm{C}$ to rt; (ii) epichlorohydrin, $0^{\circ} \mathrm{C}$ to rt; (b) (i) $\mathbf{6}$ (for 2a), 8c (for 2b), 10a (for 2c), $\mathbf{1 0 c}$ (for 2d), 14a (for 2e), 14b (for 2f), or 14c (for 2g), 2-propanol, reflux; (ii) $4 \mathrm{M} \mathrm{HCl} / E t O A c$, EtOAc, rt; (c) (i) 15b (for 3a), 16b (for 3b), or 18b (for 3c), 2-propanol, reflux; (ii) $4 \mathrm{~m} \mathrm{HCl} / \mathrm{EtOAc}$, EtOAc, rt; (d) (i) 20b (for 4a) or 22b (for 4b), 2-propanol, reflux; (ii) $4 \mathrm{M} \mathrm{HCl/EtOAc,} \mathrm{EtOAc,} \mathrm{rt.}$ 
Table 1. Biological Activity of Biarylpiperidine and Biarylpiperazine Derivatives (2a-g)

\begin{tabular}{|c|c|c|c|c|}
\hline Compound $^{a)}$ & $\mathrm{R}$ & $\begin{array}{l}\text { Anti-veratridinine } \\
\text { IC }_{50}(\mu \mathrm{M})\end{array}$ & $\begin{array}{c}\mathrm{D}_{2} \text { binding affinity }{ }^{c)} \\
K_{\mathrm{i}}(\mu \mathrm{M})\end{array}$ & $\mathrm{C} \log D^{d)}$ \\
\hline 1 & & 0.43 & 0.61 & 3.21 \\
\hline $2 a$ & & 0.74 & $>10$ & 6.08 \\
\hline $2 \mathrm{~b}$ & & 0.22 & $>10$ & 4.34 \\
\hline $2 \mathrm{c}$ & & 0.24 & $>10$ & 5.48 \\
\hline $2 d$ & & 0.29 & $>10$ & 3.99 \\
\hline $2 \mathrm{e}$ & & 0.85 & $>10$ & 5.04 \\
\hline $2 \mathrm{f}$ & & 0.64 & $>10$ & 4.35 \\
\hline $2 \mathrm{~g}$ & & 0.75 & $>10$ & 4.46 \\
\hline
\end{tabular}

a) Each assay was carried out using a hydrochloride or dihydrochloride salt of the synthesized compounds. $b$ ) Inhibitory effect on veratridine-induced depolarization in rat cerebrocortical synaptosomes. See Experimental. c) Determined by a competition assay using $\left[{ }^{3} \mathrm{H}\right]$-spiperone. $\left.d\right) \mathrm{Clog} D$ values at $\mathrm{pH} 7.4$ were calculated from $\mathrm{Clog} P$ using Daylight version 4.9 and $\mathrm{p} K_{\mathrm{a}}$ using ChemAxon's Calculator Plugins version 5.0.0.

mine $\mathrm{D}_{2}$ receptors.

Optimal $\log D$ values, namely 1-octanol/water distribution coefficients measured at $\mathrm{pH} 7.4$, have been reported to be in the range of 1-4 for brain penetration. ${ }^{34)}$ Compounds $2 \mathbf{a}-\mathbf{g}$ were further optimized using $C \log D$ values as a reference because they had higher $\mathrm{C} \log D$ values. This optimization allowed us to obtain active compounds bearing a spiropiperidine or heteroarylpiperidine moiety. As shown in Table 2, the spiro-piperidine $\mathbf{3 b}$ and heteroarylpiperidines $\mathbf{4 a}, \mathbf{b}$ showed potent inhibitory activity for $\mathrm{Na}^{+}$channels and no binding affinity for the dopamine $\mathrm{D}_{2}$ receptors. In contrast, the spiro-piperidine 3a bearing a 1,3-dihydroisobenzofuran moiety potently inhibited the $\mathrm{Na}^{+}$channels and had a moderate affinity for the dopamine $\mathrm{D}_{2}$ receptors, and $3 \mathbf{c}$ bearing a indoline moiety showed reduced activity for the $\mathrm{Na}^{+}$channels. Compounds $\mathbf{3 b}, \mathbf{4 a}$, and $\mathbf{4 b}$ exhibited a similar level of activity, but $\mathbf{4 b}$ showed high metabolic stability in rats compared with $\mathbf{3 b}$ and $\mathbf{4 a}$ (Table 2). Compound $\mathbf{4 b}$ was further evaluated for its neuroprotective activity in a rat transient middle cerebral artery (MCA) occlusion model. ${ }^{35)}$ Briefly, compound 4b was administered intraperitoneally immediately after both occlusion and reperfusion at a dose of $30 \mathrm{mg} / \mathrm{kg}$ each 
Table 2. Biological Activity of Spiro-Piperidine and Heteroarylpiperidine Derivatives (3a-c, 4a, b)

\begin{tabular}{|c|c|c|c|c|c|c|}
\hline Structure & Compound $\left.^{a}\right)$ & $\mathrm{R}$ & $\begin{array}{l}\text { Anti-veratridine } \mathrm{e}^{b)} \\
\mathrm{IC}_{50}(\mu \mathrm{M})\end{array}$ & $\begin{array}{c}\mathrm{D}_{2} \text { binding affinity }{ }^{c)} \\
K_{\mathrm{i}}(\mu \mathrm{M})\end{array}$ & $\mathrm{C} \log D^{d)}$ & $\begin{array}{c}\mathrm{CL}(\text { male rats })^{e)} \\
(\mathrm{mL} / \mathrm{min} / \mathrm{mg} \text { protein) }\end{array}$ \\
\hline & $\mathbf{3 a}$ & & 0.44 & 2.68 & 2.62 & \\
\hline & $\mathbf{3 b}$ & & 0.46 & $>10$ & 2.26 & 0.32 \\
\hline & $3 c$ & & 1.20 & $>10$ & 2.63 & \\
\hline & $4 a$ & & 0.37 & $>10$ & 3.39 & 0.15 \\
\hline & $4 b$ & & 0.56 & $>10$ & 2.83 & 0.10 \\
\hline & SUN N8075 23$)$ & & 0.42 & $>10$ & 5.37 & \\
\hline
\end{tabular}

$a-d$ ) See footnotes in Table 1. e) Microsomal intrinsic clearance.

time. Using a computerized image analysis system, the cortical infarct areas were determined $24 \mathrm{~h}$ after the occlusion of the MCA by staining brains with 2,3,5-triphenyltetrazolium chloride (TTC). ${ }^{36)}$ Compound $\mathbf{4 b}$ reduced its infarct volume by $33 \%$ compared with the vehicle $\left[201.1 \pm 50.2 \mathrm{~mm}^{3} \quad(n=4)\right.$ vs. $302.3 \pm 26.5 \mathrm{~mm}^{3} \quad(n=6) \quad($ mean \pm S.E.M. $\left.)\right]$. SUN N8075 was also evaluated in our rat MCA occlusion model and exhibited $35 \%$ reduction in mean infarct volume compared with the vehicle $\left[166.2 \pm 38.1 \mathrm{~mm}^{3}(n=8)\right.$ vs. $255.8 \pm 31.0 \mathrm{~mm}^{3}$ $(n=8)$ (mean \pm S.E.M.)]. Therefore, our results revealed that compound 4b was as effective as SUN N8075. Then, we investigated the effect of $\mathbf{4 b}$ on neurotoxin receptor site 2 of the $\mathrm{Na}^{+}$channels. Compound $\mathbf{4 b}$ displaced $\left[{ }^{3} \mathrm{H}\right] \mathrm{BTX}$ with higher affinity $\left(\mathrm{IC}_{50}: 0.30 \mu \mathrm{M}\right)$ than SUN N8075 $\left(\mathrm{IC}_{50}: 0.75 \mu \mathrm{M}\right),{ }^{23)}$ further suggesting that $\mathbf{4 b}$ may block $\mathrm{Na}^{+}$channels with high use dependency.

In conclusion, we discovered 3-amino-1-(5-indanyloxy)2-propanol derivatives that are potent $\mathrm{Na}^{+}$channel blockers with low affinity for dopamine $\mathrm{D}_{2}$ receptors. In this study, we also showed that the lowering of $C \log D$ values in these compounds yielded compound $\mathbf{4 b}$, which showed potent neuroprotective activity in the rat transient MCA occlusion model. Moreover, $\mathbf{4 b}$ had a high binding affinity for neurotoxin receptor site 2 of $\mathrm{Na}^{+}$channels and may preferentially block $\mathrm{Na}^{+}$ channels during conditions of sustained cellular depolarization such as ischemia. Compound $\mathbf{4 b}$ could serve as a lead compound for further studies.

\section{Experimental}

All melting points (mp) were determined on a Büchi B-535 melting point apparatus and are uncorrected. ${ }^{1} \mathrm{H}-\mathrm{NMR}$ spectra were recorded on a Bruker ARX300 spectrometer $(300 \mathrm{MHz})$ or a Bruker AVANCE 400 spectrometer $(400 \mathrm{MHz})$, and chemical shifts are expressed in $\delta(\mathrm{ppm})$ values with tetramethylsilane as an internal standard. Abbreviations for signal patterns are as follows: s, singlet; d, doublet; t, triplet; q, quartet; m, multiplet; br, broad peak. IR spectra were obtained with a PerkinElmer Spectrum One FT-IR spectrometer. Elemental analyses were performed with a PerkinElmer 2400 II $(\mathrm{C}, \mathrm{H}, \mathrm{N})$ and were within $\pm 0.4 \%$ of the theoretical values. LC/MS spectra were recorded on a Waters LC/MS system using a Acquity UPLC BEH $\mathrm{C}_{18}$ column $(2 \times 50 \mathrm{~mm})$ coupled with micromass ZQ as a MS detector, and a gradient of 5-98\% B over $1 \mathrm{~min}$ was used. TFA $0.05 \%(\mathrm{v} / \mathrm{v})$ was added to solvents $\mathrm{A}$ and $\mathrm{B}$ (water (A) and acetonitrile (B)). Mass spectra were obtained on a ThermoFisher FINNIGAN LXQ mass spectrometer. Column chromatography was carried out on silica gel (Fuji Silysia Chemical Ltd., BW-300) or Chromatorex NH DM1020 (Fuji Silysia Chemical Ltd., 100-200 mesh).

1-(4-Phenoxyphenyl)piperazine (6) A mixture of 4-phenoxyaniline (5) $(5.0 \mathrm{~g}, 27.0 \mathrm{mmol})$ and 2,2'-dichloroethylamine hydrochloride $(4.8 \mathrm{~g}, 27.0 \mathrm{mmol})$ was heated to $200^{\circ} \mathrm{C}$ with stirring for $4 \mathrm{~h}$. After cooling, $1 \mathrm{~m}$ aqueous $\mathrm{NaOH}$ was added, and the whole was extracted with ethyl acetate (EtOAc). The extract was dried over anhydrous $\mathrm{MgSO}_{4}$ and concentrated in vacuo. The residue was purified by column chromatography on silica gel $\left(\mathrm{CHCl}_{3} /\right.$ methanol $\left.(\mathrm{MeOH})=20 / 1\right)$ to give 6 as a pale yellow solid $\left(4.4 \mathrm{~g}, 64 \%\right.$ yield). mp $114^{\circ} \mathrm{C} .{ }^{1} \mathrm{H}-\mathrm{NMR}$ $\left(\mathrm{CDCl}_{3}\right) \delta$ : 3.03-3.06 (4H, m), 3.09-3.12 (4H, m), 6.90-7.05 $(7 \mathrm{H}, \mathrm{m}), 7.27-7.32(2 \mathrm{H}, \mathrm{m})$. LC/MS [electrospray ionization 


\section{(ESI)] $m / z: 255[\mathrm{M}+\mathrm{H}]^{+}$.}

tert-Butyl 4-Biphenyl-4-yl-4-hydroxypiperidine-1-carboxylate (8a) A $0.5 \mathrm{M}$ solution of 4-biphenyl magnesium bromide $(11 \mathrm{~mL}, 5.5 \mathrm{mmol})$ in tetrahydrofuran (THF) was added dropwise to a solution of tert-butyl 4-oxopiperidine1-carboxylate (7a) $(1.0 \mathrm{~g}, 5.0 \mathrm{mmol})$ in $\mathrm{THF}(25 \mathrm{~mL})$ at $0^{\circ} \mathrm{C}$ under a nitrogen atmosphere. The mixture was stirred for $2 \mathrm{~h}$ at the same temperature. One molar aqueous $\mathrm{HCl}$ was then added, and the whole was extracted with EtOAc. The extract was washed with saturated $\mathrm{NaHCO}_{3}$ solution, dried over anhydrous $\mathrm{MgSO}_{4}$, and concentrated in vacuo. The residue was purified by column chromatography on silica gel (hexane/ $\mathrm{EtOAc}=4 / 1)$ to give $8 \mathbf{a}$ as a colorless solid $(0.58 \mathrm{~g}, 33 \%$ yield $)$. mp $159-163^{\circ} \mathrm{C} .{ }^{1} \mathrm{H}-\mathrm{NMR}\left(\mathrm{CDCl}_{3}\right) \delta: 1.49(9 \mathrm{H}, \mathrm{s}), 1.78(2 \mathrm{H}, \mathrm{d}$, $J=12.3 \mathrm{~Hz}), 2.04(2 \mathrm{H}, \mathrm{m}), 3.27(2 \mathrm{H}, \mathrm{t}, J=12.3 \mathrm{~Hz}), 4.04(2 \mathrm{H}$, $\mathrm{m}), 7.35(1 \mathrm{H}, \mathrm{t}, J=7.5 \mathrm{~Hz}), 7.44(2 \mathrm{H}, \mathrm{t}, J=7.5 \mathrm{~Hz}), 7.53-7.62$ $(6 \mathrm{H}, \mathrm{m})$. MS [atmospheric pressure chemical ionization (APCI)] $m / z: 352[\mathrm{M}-\mathrm{H}]^{-}$.

Ethyl 4-Biphenyl-4-yl-4-hydroxypiperidine-1-carboxylate (8b) This compound was prepared as a colorless solid ( $36 \%$ yield) by the same procedure as described for $\mathbf{8 a}$ using ethyl 4-oxopiperidine-1-carboxylate (7b) instead of 7a. mp 95$100^{\circ} \mathrm{C} .{ }^{1} \mathrm{H}-\mathrm{NMR}\left(\mathrm{CDCl}_{3}\right) \delta: 1.29(3 \mathrm{H}, \mathrm{t}, J=7.2 \mathrm{~Hz}), 1.80(2 \mathrm{H}$, d, $J=12.6 \mathrm{~Hz}), 2.05(2 \mathrm{H}, \mathrm{m}), 3.32(2 \mathrm{H}, \mathrm{t}, J=13.1 \mathrm{~Hz}), 4.14(2 \mathrm{H}$, m), $4.17(2 \mathrm{H}, \mathrm{q}, J=7.2 \mathrm{~Hz}), 7.35(1 \mathrm{H}, \mathrm{t}, J=7.2 \mathrm{~Hz}), 7.45(2 \mathrm{H}, \mathrm{t}$, $J=7.4 \mathrm{~Hz}$ ), 7.53-7.62 (6H, m). MS (APCI) $m / z: 324[\mathrm{M}-\mathrm{H}]^{-}$.

4-Biphenyl-4-ylpiperidin-4-ol (8c) A mixture of $\mathbf{8 b}$ $(1.4 \mathrm{~g}, 4.2 \mathrm{mmol})$ and $5 \mathrm{M}$ aqueous $\mathrm{NaOH}(10 \mathrm{~mL})$ in $\mathrm{EtOH}$ $(20 \mathrm{~mL})$ was refluxed overnight and then concentrated in vacuo. The residue was diluted with $\mathrm{H}_{2} \mathrm{O}$, and the whole was extracted with $\mathrm{CH}_{2} \mathrm{Cl}_{2}$. The extract was dried over anhydrous $\mathrm{MgSO}_{4}$ and concentrated in vacuo. The residue was purified by column chromatography on $\mathrm{NH}$-silica gel $\left(\mathrm{CH}_{2} \mathrm{Cl}_{2} /\right.$ $\mathrm{MeOH}=2 / 1)$ to give $8 \mathbf{c}$ as a colorless solid $(0.74 \mathrm{~g}, 70 \%$ yield $)$. mp $183-186^{\circ} \mathrm{C} .{ }^{1} \mathrm{H}-\mathrm{NMR}\left(\mathrm{CDCl}_{3}\right) \delta: 1.77-1.81(2 \mathrm{H}, \mathrm{m}), 2.08$ $(2 \mathrm{H}, \mathrm{dt}, J=4.5,12.8 \mathrm{~Hz}), 2.98-3.02(2 \mathrm{H}, \mathrm{m}), 3.15(2 \mathrm{H}, \mathrm{dt}$, $J=2.4,12.0 \mathrm{~Hz}), 7.34(1 \mathrm{H}, \mathrm{t}, J=6.9 \mathrm{~Hz}), 7.44(2 \mathrm{H}, \mathrm{t}, J=6.9 \mathrm{~Hz})$, 7.58-7.61 (6H, m). LC/MS (ESI) $m / z: 254[\mathrm{M}+\mathrm{H}]^{+}$.

tert-Butyl 4-[4-(Benzyloxy)phenyl]-4-hydroxypiperidine1-carboxylate (8d) This compound was prepared as a colorless solid ( $55 \%$ yield) by the same procedure as described for 8a using 4-benzyloxyphenyl magnesium bromide prepared from (4-benzyloxy)bromobenzene instead of 4-biphenyl magnesium bromide. mp $123^{\circ} \mathrm{C} .{ }^{1} \mathrm{H}-\mathrm{NMR}\left(\mathrm{CDCl}_{3}\right) \delta: 1.48(9 \mathrm{H}, \mathrm{s})$, $1.72-1.75(2 \mathrm{H}, \mathrm{m}), 1.97(2 \mathrm{H}, \mathrm{m}), 3.24(2 \mathrm{H}, \mathrm{t}, J=12.3 \mathrm{~Hz}), 4.00$ $(2 \mathrm{H}, \mathrm{brs}), 5.07(2 \mathrm{H}, \mathrm{s}), 6.95-6.98(2 \mathrm{H}, \mathrm{m}), 7.32-7.35(1 \mathrm{H}, \mathrm{m})$, 7.36-7.44 (6H, m). MS (APCI) $m / z: 383[\mathrm{M}-\mathrm{H}]^{-}$.

4-Bihenyl-4-yl-1,2,3,6-tetrahydropyridine (9a) To a solution of $8 \mathbf{a}(0.58 \mathrm{~g}, 1.6 \mathrm{mmol})$ in $\mathrm{CH}_{2} \mathrm{Cl}_{2}(5 \mathrm{~mL})$ was added TFA $(1.4 \mathrm{~mL})$ at $0^{\circ} \mathrm{C}$. After stirring for $6 \mathrm{~h}$ at room temperature, the reaction mixture was poured into $1 \mathrm{~m}$ aqueous $\mathrm{NaOH}$, and the whole was extracted with EtOAc. The extract was dried over anhydrous $\mathrm{MgSO}_{4}$ and concentrated in vacuo. Compound 9a was obtained as a colorless solid $(0.33 \mathrm{~g}, 69 \%$ yield). mp $261{ }^{\circ} \mathrm{C} .{ }^{1} \mathrm{H}-\mathrm{NMR}\left(\mathrm{CDCl}_{3}\right) \delta: 2.48-2.57(2 \mathrm{H}, \mathrm{m}), 3.15$ $(2 \mathrm{H}, \mathrm{t}, J=5.7 \mathrm{~Hz}), 3.58(2 \mathrm{H}, \mathrm{q}, J=2.9 \mathrm{~Hz}), 6.19-6.21(1 \mathrm{H}, \mathrm{m})$, 7.32-7.36 (1H, m), 7.42-7.48 (4H, m), 7.56-7.61 (4H, m). LC/ MS (ESI) $m / z: 236[\mathrm{M}+\mathrm{H}]^{+}$.

4-[4-(Benzyloxy)phenyl]-1,2,3,6-tetrahydropyridine (9b) To a solution of $8 \mathbf{d}(1.53 \mathrm{~g}, 4.0 \mathrm{mmol})$ in $\mathrm{CH}_{2} \mathrm{Cl}_{2}(20 \mathrm{~mL})$ was added TFA $(3.1 \mathrm{~mL})$ at $0^{\circ} \mathrm{C}$. After stirring for $1 \mathrm{~h}$ at room temperature, the reaction mixture was poured into $1 \mathrm{~m}$ aqueous $\mathrm{NaOH}$, and the precipitate was collected by filtration. Compound 9b was obtained as a colorless solid $(1.03 \mathrm{~g}, 97 \%$ yield). ${ }^{1} \mathrm{H}-\mathrm{NMR}\left(\mathrm{CDCl}_{3}\right) \delta: 2.40-2.50(2 \mathrm{H}, \mathrm{m}), 3.12(2 \mathrm{H}, \mathrm{t}$, $J=5.7 \mathrm{~Hz}), 3.53(2 \mathrm{H}, \mathrm{dd}, J=2.6,5.7 \mathrm{~Hz}), 5.07(2 \mathrm{H}, \mathrm{s}), 6.00-6.09$ $(1 \mathrm{H}, \mathrm{m}), 6.94(2 \mathrm{H}, \mathrm{d}, J=8.7 \mathrm{~Hz}), 7.29-7.35(3 \mathrm{H}, \mathrm{m}), 7.36-7.46$ $(4 \mathrm{H}, \mathrm{m}) . \mathrm{LC} / \mathrm{MS}(\mathrm{ESI}) \mathrm{m} / z: 266[\mathrm{M}+\mathrm{H}]^{+}$.

4-Biphenyl-4-ylpiperidine (10a) To a solution of 9a $(0.32 \mathrm{~g}, 1.2 \mathrm{mmol})$ in $\mathrm{MeOH}(20 \mathrm{~mL})$ and $\mathrm{H}_{2} \mathrm{O}(5 \mathrm{~mL})$ was added $10 \%$ palladium on carbon $(15 \mathrm{w} / \mathrm{w} \% ; 0.10 \mathrm{~g})$, and the mixture was stirred at $60^{\circ} \mathrm{C}$ under a hydrogen atmosphere for $4 \mathrm{~h}$. The catalyst was removed by filtration, and the filtrate was concentrated in vacuo. To the residue was added $1 \mathrm{~m}$ aqueous $\mathrm{NaOH}$, and the whole was extracted with EtOAc. The extract was dried over anhydrous $\mathrm{MgSO}_{4}$ and concentrated in vacuo. Compound 10a was obtained as a colorless solid $\left(0.22 \mathrm{~g}, 80 \%\right.$ yield). mp $109-114^{\circ} \mathrm{C} .{ }^{1} \mathrm{H}-\mathrm{NMR}\left(\mathrm{CDCl}_{3}\right) \delta: 1.68$ $(2 \mathrm{H}, \mathrm{dq}, J=3.9,12.5 \mathrm{~Hz}), 1.88(2 \mathrm{H}, \mathrm{d}, J=13.2 \mathrm{~Hz}), 2.63-2.68$ $(1 \mathrm{H}, \mathrm{m}), 2.77(2 \mathrm{H}, \mathrm{dt}, J=2.4,12.2 \mathrm{~Hz}), 3.21(2 \mathrm{H}, \mathrm{d}, J=12.0 \mathrm{~Hz})$, $7.29-7.35(3 \mathrm{H}, \mathrm{m}), 7.43(2 \mathrm{H}, \mathrm{t}, J=7.5 \mathrm{~Hz}), 7.56(4 \mathrm{H}, \mathrm{dd}, J=7.7$, $11.6 \mathrm{~Hz})$. LC/MS (ESI) $m / z: 238[\mathrm{M}+\mathrm{H}]^{+}$.

tert-Butyl 4-(4-Pyridin-3-ylphenyl)piperidine-1-carboxylate (10b) To a solution of $9 \mathbf{b}(0.98 \mathrm{~g}, 3.7 \mathrm{mmol})$ in THF $(20 \mathrm{~mL})$ was added di-tert-butyl dicarbonate $(0.89 \mathrm{~g}, 4.1 \mathrm{mmol})$. The mixture was heated to reflux for $3 \mathrm{~h}$ and then concentrated in vacuo. The residue was extracted with EtOAc, and the extract was dried over anhydrous $\mathrm{MgSO}_{4}$ and concentrated in vасио. The resulting crystals were dissolved in $\mathrm{EtOH}(14 \mathrm{~mL})$ and THF $(7 \mathrm{~mL})$, and $10 \%$ palladium on carbon $(15 \mathrm{w} / \mathrm{w} \%$; $0.34 \mathrm{~g}$ ) was added. The mixture was then stirred at $50^{\circ} \mathrm{C}$ under a hydrogen atmosphere for $5 \mathrm{~h}$. The catalyst was removed by filtration, and the filtrate was concentrated in vacuo. To the resulting crystals and pyridine $(0.35 \mathrm{~mL})$ in $\mathrm{CH}_{2} \mathrm{Cl}_{2}(10 \mathrm{~mL})$ was added dropwise a solution of trifluoromethanesulfonic anhydride $(0.52 \mathrm{~mL})$ in $\mathrm{CH}_{2} \mathrm{Cl}_{2}(3 \mathrm{~mL})$ at $0^{\circ} \mathrm{C}$. After stirring for $1 \mathrm{~h}$ at room temperature, the reaction mixture was concentrated in vacuo. The residue was extracted with EtOAc, and the extract was dried over anhydrous $\mathrm{MgSO}_{4}$ and concentrated in vacuo. The residual oil was dissolved in toluene $(10 \mathrm{~mL})$ and EtOH $(1.0 \mathrm{~mL})$. To the solution was added pyridine3-boronic acid $(0.35 \mathrm{~g}, 2.8 \mathrm{mmol})$, tetrakis(triphenylphosphine) palladium $(0)(0.13 \mathrm{~g}, 0.12 \mathrm{mmol})$, and $2 \mathrm{M}$ aqueous $\mathrm{Na}_{2} \mathrm{CO}_{3}$ $(2.3 \mathrm{~mL})$. The mixture was then heated to $100^{\circ} \mathrm{C}$ with stirring for $15 \mathrm{~h}$. After cooling, $\mathrm{H}_{2} \mathrm{O}$ was added, and the whole was extracted with EtOAc. The extract was washed with brine, dried over anhydrous $\mathrm{MgSO}_{4}$, and concentrated in vacuo. The residue was purified by column chromatography on silica gel (hexane/EtOAc $=2 / 1)$ to give $10 \mathrm{~b}(0.67 \mathrm{~g}, 4$ steps $54 \%$ yield) as a colorless solid. mp $104^{\circ} \mathrm{C} .{ }^{1} \mathrm{H}-\mathrm{NMR}\left(\mathrm{CDCl}_{3}\right) \delta: 1.49(9 \mathrm{H}$, s), $1.61-1.71(2 \mathrm{H}, \mathrm{m}), 1.85-1.88(2 \mathrm{H}, \mathrm{m}), 2.68-2.74(1 \mathrm{H}, \mathrm{m})$, $2.77-2.93(2 \mathrm{H}, \mathrm{m}), 4.27(2 \mathrm{H}, \mathrm{m}), 7.31-7.38(3 \mathrm{H}, \mathrm{m}), 7.54(2 \mathrm{H}$, $\mathrm{d}, J=8.2 \mathrm{~Hz}), 7.85-7.88(1 \mathrm{H}, \mathrm{m}), 8.58(1 \mathrm{H}, \mathrm{dd}, J=1.5,5.1 \mathrm{~Hz})$, $8.84(1 \mathrm{H}, \mathrm{m})$. LC/MS (ESI) $m / z: 339[\mathrm{M}+\mathrm{H}]^{+}$.

\section{3-(4-Piperidin-4-ylphenyl)pyridine Dihydrochloride} (10c) To a solution of $10 \mathrm{~b}(0.59 \mathrm{~g}, 1.7 \mathrm{mmol})$ in EtOAc $(8 \mathrm{~mL})$ was added $2 \mathrm{M} \mathrm{HCl}-\mathrm{MeOH}$ solution $(8.7 \mathrm{~mL})$. After stirring for $1 \mathrm{~h}$ at room temperature, the precipitate was collected by filtration. Compound 10 $\mathrm{c}$ was obtained as a colorless solid $(0.48 \mathrm{~g}$, $89 \%$ yield). mp $276-280^{\circ} \mathrm{C} .{ }^{1} \mathrm{H}-\mathrm{NMR}\left(\mathrm{CD}_{3} \mathrm{OD}\right) \delta: 1.92-2.03$ $(2 \mathrm{H}, \mathrm{m}), 2.11-2.15(2 \mathrm{H}, \mathrm{m}), 3.04(1 \mathrm{H}, \mathrm{tt}, J=3.6,12.3 \mathrm{~Hz})$, $3.15-3.21(2 \mathrm{H}, \mathrm{m}), 3.52-3.55(2 \mathrm{H}, \mathrm{m}), 7.53(2 \mathrm{H}, \mathrm{d}, J=8.2 \mathrm{~Hz})$, 
$7.83(2 \mathrm{H}, \mathrm{d}, J=8.2 \mathrm{~Hz}), 8.15(1 \mathrm{H}, \mathrm{dd}, J=5.7,8.2 \mathrm{~Hz}), 8.82(1 \mathrm{H}$, d, $J=5.7 \mathrm{~Hz}), 8.89-8.92(1 \mathrm{H}, \mathrm{m}), 9.17(1 \mathrm{H}, \mathrm{d}, J=2.1 \mathrm{~Hz}) . \mathrm{LC} /$ MS (ESI) $m / z: 239[\mathrm{M}+\mathrm{H}]^{+}$.

tert-Butyl 4-(5-Bromopyridin-2-yl)piperazine-1-carboxylate (12a) A mixture of tert-butyl piperazine-1-carboxylate (11) $(5.0 \mathrm{~g}, 26.9 \mathrm{mmol}), 2,5$-dibromopyridine $(6.4 \mathrm{~g}, 26.9 \mathrm{mmol})$, and $N, N$-diisopropylethylamine $(6.9 \mathrm{~g}, 51.7 \mathrm{mmol})$ in $N$ methylpyrrolidone $(70 \mathrm{~mL})$ was heated to $120^{\circ} \mathrm{C}$ with stirring for $5 \mathrm{~h}$. After cooling, $\mathrm{H}_{2} \mathrm{O}$ was added, and the whole was extracted with EtOAc. The extract was washed with brine, dried over anhydrous $\mathrm{MgSO}_{4}$, and concentrated in vacuo. The residue was purified by column chromatography on silica gel (hexane/EtOAc $=10 / 1)$ to give $\mathbf{1 2 a}$ as a pale yellow solid (4.5 g, 49\% yield). mp $89^{\circ} \mathrm{C} .{ }^{1} \mathrm{H}-\mathrm{NMR}\left(\mathrm{CDCl}_{3}\right) \delta: 1.48(9 \mathrm{H}$, s), $3.47-3.57(8 \mathrm{H}, \mathrm{m}), 6.55(1 \mathrm{H}, \mathrm{d}, J=9.0 \mathrm{~Hz}), 7.55(1 \mathrm{H}, \mathrm{dd}$, $J=2.4,9.0 \mathrm{~Hz}), 8.20(1 \mathrm{H}, \mathrm{d}, J=2.4 \mathrm{~Hz})$ LC/MS (ESI) $\mathrm{m} / z: 342$ $[\mathrm{M}+\mathrm{H}]^{+}, 344[\mathrm{M}+2 \mathrm{H}]^{2+}$.

tert-Butyl 4-(6-Chloropyridazin-3-yl)piperazine-1-carboxylate (12b) This compound was prepared as a pale yellow solid (62\% yield) by the same procedure as described for 12a using 3,6-dichloropyridazine instead of 2,5-dibromopyridine. $\mathrm{mp} 172^{\circ} \mathrm{C} .{ }^{1} \mathrm{H}-\mathrm{NMR}\left(\mathrm{CDCl}_{3}\right) \delta$ : $1.49(9 \mathrm{H}, \mathrm{s}), 3.56-3.62$ $(8 \mathrm{H}, \mathrm{m}), 6.90(1 \mathrm{H}, \mathrm{d}, J=9.9 \mathrm{~Hz}), 7.24(1 \mathrm{H}, \mathrm{d}, J=9.9 \mathrm{~Hz}) . \mathrm{LC} /$ MS (ESI) $m / z: 299[\mathrm{M}+\mathrm{H}]^{+}$.

tert-Butyl 4-(5-Phenylpyridin-2-yl)piperazine-1-carboxylate (13a) To a solution of 12a $(0.68 \mathrm{~g}, 2.0 \mathrm{mmol})$ and $2 \mathrm{M}$ aqueous $\mathrm{Na}_{2} \mathrm{CO}_{3}(5 \mathrm{~mL})$ in dioxane $(10 \mathrm{~mL})$ was added phenylboronic acid $(0.36 \mathrm{~g}, 3.0 \mathrm{mmol})$ and tetrakis(triphenylphosphine)palladium $(0) \quad(0.11 \mathrm{~g}, \quad 0.10 \mathrm{mmol})$. The mixture was heated to $100^{\circ} \mathrm{C}$ with stirring for $6 \mathrm{~h}$. After cooling, $\mathrm{H}_{2} \mathrm{O}$ was added, and the whole was extracted with EtOAc. The extract was washed with brine, dried over anhydrous $\mathrm{MgSO}_{4}$, and concentrated in vacuo. The residue was purified by column chromatography on silica gel (hexane/ EtOAc $=4 / 1)$ to give $13 \mathrm{a}$ as a pale yellow solid $(0.52 \mathrm{~g}, 77 \%$ yield). mp $133-137^{\circ} \mathrm{C} .{ }^{1} \mathrm{H}-\mathrm{NMR}\left(\mathrm{CDCl}_{3}\right) \delta: 1.46(9 \mathrm{H}, \mathrm{s}), 3.58$ $(8 \mathrm{H}, \mathrm{m}), 6.73(1 \mathrm{H}, \mathrm{d}, J=9.3 \mathrm{~Hz}), 7.31-7.34(1 \mathrm{H}, \mathrm{m}), 7.43(2 \mathrm{H}, \mathrm{t}$, $J=7.2 \mathrm{~Hz}), 7.51-7.54(2 \mathrm{H}, \mathrm{m}), 7.74(1 \mathrm{H}, \mathrm{d}, J=8.7 \mathrm{~Hz}), 8.46(1 \mathrm{H}$, s). LC/MS (ESI) $m / z: 340[\mathrm{M}+\mathrm{H}]^{+}$.

tert-Butyl 4-(6-Phenylpyridazin-3-yl)piperazine-1-carboxylate (13b) This compound was prepared as a pale yellow solid $(64 \%$ yield) by the same procedure as described for 13a using 12b instead of 12a. mp 177-180 ${ }^{\circ} \mathrm{C} .{ }^{1} \mathrm{H}-\mathrm{NMR}$ $\left(\mathrm{CDCl}_{3}\right) \delta: 1.50(9 \mathrm{H}, \mathrm{s}), 3.59-3.62(4 \mathrm{H}, \mathrm{m}), 3.71(4 \mathrm{H}, \mathrm{m}), 7.00$ $(1 \mathrm{H}, \mathrm{d}, J=9.6 \mathrm{~Hz}), 7.41-7.51(3 \mathrm{H}, \mathrm{m}), 7.69(1 \mathrm{H}, \mathrm{d}, J=9.9 \mathrm{~Hz})$, $8.02(2 \mathrm{H}, \mathrm{dd}, J=1.4,8.0 \mathrm{~Hz})$. LC/MS (ESI) $m / z: 341[\mathrm{M}+\mathrm{H}]^{+}$.

tert-Butyl 4-(4-Pyridin-3-ylphenyl)piperazine-1-carboxylate (13c) This compound was prepared as a pale yellow solid $(47 \%$ yield) by the same procedure as described for 13a using commercially available 12c instead of 12a and pyridine-3-boronic acid instead of phenylboronic acid. $\mathrm{mp}$ $150^{\circ} \mathrm{C} .{ }^{1} \mathrm{H}-\mathrm{NMR}\left(\mathrm{CDCl}_{3}\right) \delta: 1.49(9 \mathrm{H}, \mathrm{s}), 3.20-3.23(4 \mathrm{H}, \mathrm{m})$, 3.59-3.63 (4H, m), $7.02(2 \mathrm{H}, \mathrm{d}, J=8.7 \mathrm{~Hz}), 7.32(1 \mathrm{H}, \mathrm{dd}, J=5.1$, $7.8 \mathrm{~Hz}), 7.52(2 \mathrm{H}, \mathrm{d}, J=8.7 \mathrm{~Hz}), 7.82-7.85(1 \mathrm{H}, \mathrm{m}), 8.53(1 \mathrm{H}$, $\mathrm{dd}, J=1.5,5.1 \mathrm{~Hz}), 8.82(1 \mathrm{H}, \mathrm{d}, J=2.4 \mathrm{~Hz})$ LC/MS (ESI) $m / z$ : $340[\mathrm{M}+\mathrm{H}]^{+}$.

1-(5-Phenylpyridin-2-yl)piperazine (14a) To a solution of $13 \mathrm{a}(0.52 \mathrm{~g}, 1.5 \mathrm{mmol})$ in $\mathrm{CH}_{2} \mathrm{Cl}_{2}(2 \mathrm{~mL})$ was added trifluoroacetic acid $(2 \mathrm{~mL})$ at $0^{\circ} \mathrm{C}$. After stirring for $1 \mathrm{~h}$ at room temperature, the reaction mixture was poured into $1 \mathrm{M}$ aqueous $\mathrm{NaOH}$, and the whole was extracted with $\mathrm{CH}_{2} \mathrm{Cl}_{2}$. The extract was dried over anhydrous $\mathrm{MgSO}_{4}$ and concentrated in vacuo. Compound 14a was obtained as a colorless solid $(0.33 \mathrm{~g}$, $90 \%$ yield). mp $150-153{ }^{\circ} \mathrm{C} .{ }^{1} \mathrm{H}-\mathrm{NMR}\left(\mathrm{CDCl}_{3}\right) \delta: 3.00-3.03$ (4H, m), 3.54-3.58 (4H, m), $6.72(1 \mathrm{H}, \mathrm{d}, J=9.0 \mathrm{~Hz}), 7.31-7.45$ $(1 \mathrm{H}, \mathrm{m}), 7.40-7.45(2 \mathrm{H}, \mathrm{m}), 7.51-7.54(2 \mathrm{H}, \mathrm{m}), 7.72(1 \mathrm{H}, \mathrm{dd}$, $J=2.4,9.0 \mathrm{~Hz}), 8.45(1 \mathrm{H}, \mathrm{d}, J=2.4 \mathrm{~Hz}) . \mathrm{LC} / \mathrm{MS}(\mathrm{ESI}) \mathrm{m} / z: 240$ $[\mathrm{M}+\mathrm{H}]^{+}$.

3-Phenyl-6-piperazin-1-ylpyridazine (14b) This compound was prepared as a pale yellow solid ( $83 \%$ yield) by the same procedure as described for 14a using $\mathbf{1 3 b}$ instead of 13a. $\mathrm{mp} 156-158^{\circ} \mathrm{C}$. ${ }^{1} \mathrm{H}-\mathrm{NMR}\left(\mathrm{CDCl}_{3}\right) \delta$ : $3.02-3.05(4 \mathrm{H}, \mathrm{m})$, $3.68-3.70(4 \mathrm{H}, \mathrm{m}), 6.98(1 \mathrm{H}, \mathrm{d}, J=9.8 \mathrm{~Hz}), 7.38-7.42(1 \mathrm{H}, \mathrm{m})$, $7.45-7.49(2 \mathrm{H}, \mathrm{m}), 7.66(1 \mathrm{H}, \mathrm{d}, J=9.8 \mathrm{~Hz}), 8.00-8.02(2 \mathrm{H}, \mathrm{m})$. LC/MS (ESI) $m / z: 241[\mathrm{M}+\mathrm{H}]^{+}$.

1-(4-Pyridin-3-ylphenyl)piperazine (14c) This compound was prepared as a pale yellow solid ( $81 \%$ yield) by the same procedure as described for 14a using 13c instead of 13a. mp $156-158^{\circ} \mathrm{C} .{ }^{1} \mathrm{H}-\mathrm{NMR}\left(\mathrm{CDCl}_{3}\right) \delta$ : $3.04-3.08(4 \mathrm{H}, \mathrm{m})$, $3.21-3.24$ (4H, m), $7.02(2 \mathrm{H}, \mathrm{d}, J=8.7 \mathrm{~Hz}), 7.32(1 \mathrm{H}, \mathrm{dd}, J=4.5$, $8.0 \mathrm{~Hz}), 7.51(2 \mathrm{H}, \mathrm{d}, J=8.4 \mathrm{~Hz}), 7.81-7.85(1 \mathrm{H}, \mathrm{m}), 8.52(1 \mathrm{H}$, $\mathrm{dd}, J=1.5,4.5 \mathrm{~Hz}), 8.82(1 \mathrm{H}, \mathrm{d}, J=2.4 \mathrm{~Hz}) . \mathrm{LC} / \mathrm{MS}$ (ESI) $m / z$ : $240[\mathrm{M}+\mathrm{H}]^{+}$.

Ethyl Spiro[isobenzofuran-1(3H),4'-piperidine]-1'-carboxylate (15a) This compound was synthesized as a colorless oil $\left(85 \%\right.$ yield) by the procedure of Kubota et al. ${ }^{28)}$ ${ }^{1} \mathrm{H}-\mathrm{NMR}\left(\mathrm{CDCl}_{3}\right) \delta: 1.29(3 \mathrm{H}, \mathrm{t}, J=7.1 \mathrm{~Hz}), 1.71-1.75(2 \mathrm{H}, \mathrm{m})$, $1.84(2 \mathrm{H}, \mathrm{dt}, J=4.8,13.0 \mathrm{~Hz}), 3.23(2 \mathrm{H}, \mathrm{t}, J=12.2 \mathrm{~Hz}), 4.09-$ $4.14(2 \mathrm{H}, \mathrm{m}), 4.17(2 \mathrm{H}, \mathrm{q}, J=7.1 \mathrm{~Hz}), 5.08(2 \mathrm{H}, \mathrm{s}), 7.07-7.10$ $(1 \mathrm{H}, \mathrm{m}), 7.20-7.29(3 \mathrm{H}, \mathrm{m})$. LC/MS (ESI) $m / z: 262[\mathrm{M}+\mathrm{H}]^{+}$.

Spiro[isobenzofuran-1(3H), $\mathbf{4}^{\prime}$-piperidine] (15b) This compound was synthesized as a colorless solid ( $83 \%$ yield) by the procedure of Kubota et al. ${ }^{28)} \mathrm{mp} 88-89^{\circ} \mathrm{C} .{ }^{1} \mathrm{H}-\mathrm{NMR}$ $\left(\mathrm{CDCl}_{3}\right) \delta$ : 1.73-1.91 (4H, m), 3.01-3.11 (4H, m), $5.08(2 \mathrm{H}, \mathrm{s})$, 7.13-7.16 (1H, m), 7.21-7.29 (3H, m). LC/MS (ESI) $m / z: 190$ $[\mathrm{M}+\mathrm{H}]^{+}$.

tert-Butyl 3-Phenyl-1-oxa-2,4,8-triazaspiro[4,5]dec-2ene-8-carboxylate (16a) A mixture of 7b (5.0 g, 29.2 mmol), benzamidoxime $(4.0 \mathrm{~g}, 29.2 \mathrm{mmol})$, and $p$-toluenesulfonic acid monohydrate $(1.0 \mathrm{~g}, 5.8 \mathrm{mmol})$ in toluene $(30 \mathrm{~mL})$ was heated to reflux with a Dean-Stark apparatus for $7 \mathrm{~h}$. After cooling, the resulting precipitate was collected by filtration and recrystallized from 2-propanol/EtOAc to give 16a as a colorless solid $\left(4.2 \mathrm{~g}, 50 \%\right.$ yield). mp $189^{\circ} \mathrm{C} .{ }^{1} \mathrm{H}-\mathrm{NMR}\left(\mathrm{CDCl}_{3}\right) \delta: 1.28$ $(3 \mathrm{H}, \mathrm{t}, J=7.2 \mathrm{~Hz}), 1.73-1.83(2 \mathrm{H}, \mathrm{m}), 2.04-2.08(2 \mathrm{H}, \mathrm{m}), 3.40$ $(2 \mathrm{H}, \mathrm{ddd}, J=3.0,10.8,13.8 \mathrm{~Hz}), 3.91-3.95(2 \mathrm{H}, \mathrm{m}), 4.16(2 \mathrm{H}$, q, $J=7.2 \mathrm{~Hz}), 4.43(1 \mathrm{H}, \mathrm{brs}), 7.39-7.47(3 \mathrm{H}, \mathrm{m}), 7.68(2 \mathrm{H}, \mathrm{td}$, $J=1.8,6.3 \mathrm{~Hz}$ ). LC/MS (ESI) $\mathrm{m} / z: 290[\mathrm{M}+\mathrm{H}]^{+}$.

3-Phenyl-1-oxa-2,4,8-triazaspiro[4,5]dec-2-ene (16b) A mixture of $16 \mathrm{a}(4.2 \mathrm{~g}, 14.6 \mathrm{mmol})$ and $\mathrm{Ba}(\mathrm{OH})_{2} \cdot 8 \mathrm{H}_{2} \mathrm{O}(6.4 \mathrm{~g}$, $20.4 \mathrm{mmol})$ in $\mathrm{EtOH}(30 \mathrm{~mL})$ and $\mathrm{H}_{2} \mathrm{O}(20 \mathrm{~mL})$ was heated to reflux with stirring overnight. The mixture was then concentrated in vacuo, and the residue was diluted with $\mathrm{H}_{2} \mathrm{O}$. The resulting precipitate was removed by filtration, and the filtrate was extracted with $\mathrm{CH}_{2} \mathrm{Cl}_{2}$. The extract was dried over anhydrous $\mathrm{MgSO}_{4}$ and concentrated in vacuo. The residue was washed with hexane/EtOAc (1/1) to give $\mathbf{1 6 b}$ as a colorless solid $\left(2.2 \mathrm{~g}, 68 \%\right.$ yield). mp $169^{\circ} \mathrm{C} .{ }^{1} \mathrm{H}-\mathrm{NMR}\left(\mathrm{CDCl}_{3}\right) \delta: 1.79$ 1.85 (2H, m), 2.0-2.06 (2H, m), 2.93-2.97 (2H, m), 2.99-3.08 $(2 \mathrm{H}, \mathrm{m}), 4.45$ (1H, br s), 7.27-7.46 (3H, m), 7.68-7.71 (2H, m). LC/MS (ESI) $m / z: 218[\mathrm{M}+\mathrm{H}]^{+}$.

tert-Butyl 1-(Trifluoroacetyl)-1,2-dihydro-1'H-spiro[in- 
dole-3,4'-piperidine]-1'-carboxylate (18a) To a solution of commercially available tert-butyl 1,2 -dihydro- $1^{\prime} H$-spiro[indole3,4'-piperidine]-1'-carboxylate $(\mathbf{1 7})(0.8 \mathrm{~g}, 2.8 \mathrm{mmol})$ and triethylamine $(0.46 \mathrm{~mL}, 3.3 \mathrm{mmol})$ in $\mathrm{CH}_{2} \mathrm{Cl}_{2}(10 \mathrm{~mL})$ was added trifluoroacetic anhydride $(0.41 \mathrm{~mL}, 2.9 \mathrm{mmol})$ at $0^{\circ} \mathrm{C}$. After stirring for $4 \mathrm{~h}$ at the same temperature, $\mathrm{H}_{2} \mathrm{O}$ was added, and the whole was extracted with $\mathrm{CH}_{2} \mathrm{Cl}_{2}$. The extract was dried over anhydrous $\mathrm{MgSO}_{4}$ and concentrated in vacuo. The residue was purified by column chromatography on silica gel (hexane/EtOAc $=5 / 1)$ to give $\mathbf{1 8 a}$ as a colorless solid $(0.99 \mathrm{~g}$, $92 \%$ yield). mp $124-125^{\circ} \mathrm{C} .{ }^{1} \mathrm{H}-\mathrm{NMR}\left(\mathrm{CDCl}_{3}\right) \delta: 1.49(9 \mathrm{H}, \mathrm{s})$, 1.66-1.70 (2H, m), $1.88(2 \mathrm{H}, \mathrm{dt}, J=4.2,13.2 \mathrm{~Hz}), 2.89(2 \mathrm{H}, \mathrm{t}$, $J=12.6 \mathrm{~Hz}), 4.13(2 \mathrm{H}, \mathrm{s}), 4.19(2 \mathrm{H}, \mathrm{m}), 7.21(2 \mathrm{H}, \mathrm{d}, J=4.2 \mathrm{~Hz})$, 7.29-7.35 (1H, m), $8.20(1 \mathrm{H}, \mathrm{d}, J=8.2 \mathrm{~Hz})$. MS (APCI) $\mathrm{m} / \mathrm{z}$ : $402\left[\mathrm{M}+\mathrm{NH}_{4}\right]^{+}$.

2,2,2-Trifluoro-1-(spiro[indole-3,4'-piperidin]-1-(2H)-yl) ethanone (18b) To a solution of 18a $(0.97 \mathrm{~g}, 2.5 \mathrm{mmol})$ in EtOAc $(10 \mathrm{~mL})$ was added $4 \mathrm{M} \mathrm{HCl}-$ EtOAc solution $(6 \mathrm{~mL})$. After stirring for $6 \mathrm{~h}$ at room temperature, saturated $\mathrm{NaHCO}_{3}$ solution was added, and the whole was extracted with $\mathrm{CH}_{2} \mathrm{Cl}_{2}$. The extract was dried over anhydrous $\mathrm{MgSO}_{4}$ and concentrated in vacuo to give $\mathbf{1 8 b}$ as a pale yellow oil $(0.41 \mathrm{~g}, 58 \%$ yield). ${ }^{1} \mathrm{H}-\mathrm{NMR}\left(\mathrm{CDCl}_{3}\right) \delta$ : $1.67-1.71(2 \mathrm{H}, \mathrm{m}), 1.95(2 \mathrm{H}, \mathrm{dt}$, $J=4.5,13.2 \mathrm{~Hz}), 2.78(2 \mathrm{H}, \mathrm{dt}, J=2.4,12.6 \mathrm{~Hz}), 3.16-3.20(2 \mathrm{H}$, m), $4.13(2 \mathrm{H}, \mathrm{s}), 7.19-7.34$ (m, 3H), 8.19 (1H, d, J=7.8 Hz). LC/ MS (ESI) $m / z: 285[\mathrm{M}+\mathrm{H}]^{+}$.

tert-Butyl 4-(3-Phenyl-1,2,4-oxadiazol-5-yl)piperidine1-carboxylate (20a) To a solution of tert-butyl 4-(ethoxycarbonyl)-piperidine-1-carboxylate (19) (6.4 g, $25.0 \mathrm{mmol})$ in THF $(20 \mathrm{~mL})$ and EtOH $(20 \mathrm{~mL})$ was added benzamidoxime $(3.4 \mathrm{~g}, 25.0 \mathrm{mmol})$, then NaOEt $(1.7 \mathrm{~g}, 25 \mathrm{mmol})$. After stirring for $3 \mathrm{~h}$ at $70^{\circ} \mathrm{C}, 1 \mathrm{M}$ aqueous $\mathrm{HCl}$ was added, and the whole was extracted with EtOAc. The extract was dried over anhydrous $\mathrm{MgSO}_{4}$ and concentrated in vacuo. The residue was purified by column chromatography on silica gel (hexane/EtOAc $=4 / 1)$ to give $\mathbf{2 0 a}$ as a colorless solid $(2.8 \mathrm{~g}$, $34 \%$ yield). mp $101-102{ }^{\circ} \mathrm{C} .{ }^{1} \mathrm{H}-\mathrm{NMR}\left(\mathrm{CDCl}_{3}\right) \delta: 1.48(9 \mathrm{H}, \mathrm{s})$, 1.85-1.95 (2H, m), $2.12(2 \mathrm{H}, \mathrm{dd}, J=3.3,13.1 \mathrm{~Hz}), 3.00(2 \mathrm{H}, \mathrm{t}$, $J=11.6 \mathrm{~Hz}), 3.15-3.20(1 \mathrm{H}, \mathrm{m}), 4.11-4.14(2 \mathrm{H}, \mathrm{m}), 7.44-7.54$ $(3 \mathrm{H}, \mathrm{m}), 8.03-8.11(2 \mathrm{H}, \mathrm{m})$. MS (APCI) $m / z: 330[\mathrm{M}+\mathrm{H}]^{+}$.

4 - (3-Phenyl-1, 2, 4 - ox a diazol-5-yl) piperidine Hydrochloride (20b) To a solution of 20a $(0.99 \mathrm{~g}, 3.0 \mathrm{mmol})$ in EtOAc $(3 \mathrm{~mL})$ was added $4 \mathrm{M} \mathrm{HCl}$-EtOAc solution $(3 \mathrm{~mL})$. After stirring for $4 \mathrm{~h}$ at room temperature, the resulting precipitate was collected by filtration and washed with EtOAc to give 20b as a colorless solid $(0.79 \mathrm{~g}, 99 \%$ yield $)$. $\mathrm{mp}$ 250-251 ${ }^{\circ} \mathrm{C} .{ }^{1} \mathrm{H}-\mathrm{NMR}\left(\mathrm{CD}_{3} \mathrm{OD}\right) \delta: 2.15(2 \mathrm{H}, \mathrm{dtd}, J=3.9,12.0$, $14.8 \mathrm{~Hz}), 2.41-2.46(2 \mathrm{H}, \mathrm{m}), 3.21-3.27(2 \mathrm{H}, \mathrm{m}), 3.49-3.56(3 \mathrm{H}$, m), 7.49-7.57 (3H, m), 8.04-8.07 (2H, m). LC/MS (ESI) $m / z$ : $230[\mathrm{M}+\mathrm{H}]^{+}$.

Benzyl 4-(1H-Benzimidazol-2-yl)piperidine-1-carboxylate (22a) To a solution of anhydrous EtOH $(16 \mathrm{~mL})$ in $\mathrm{CH}_{2} \mathrm{Cl}_{2}(18 \mathrm{~mL})$ was added dropwise acetyl chloride $(18 \mathrm{~mL})$ at $0^{\circ} \mathrm{C}$. To the reaction mixture was added dropwise benzyl 4-cyanopiperidine-1-carboxylate (21) $(2.1 \mathrm{~g}, 8.4 \mathrm{mmol})$ in $\mathrm{CH}_{2} \mathrm{Cl}_{2}(10 \mathrm{~mL})$ at the same temperature. After stirring for $2 \mathrm{~h}$ at room temperature, the resulting precipitate was collected by filtration and then dissolved in anhydrous EtOH $(50 \mathrm{~mL})$. To the solution was added $o$-phenylenediamine $(1.2 \mathrm{~g}, 11.0 \mathrm{mmol})$, and the mixture was heated to reflux for $4 \mathrm{~h}$. After cooling, $1 \mathrm{M}$ aqueous $\mathrm{NaOH}$ was added, and the whole was extracted with $\mathrm{CHCl}_{3}$. The extract was washed with $1 \mathrm{~m}$ aqueous $\mathrm{HCl}$, then brine, dried over anhydrous $\mathrm{MgSO}_{4}$, and concentrated in vacuo. The residue was purified by column chromatography on silica gel $\left(\mathrm{CHCl}_{3} / \mathrm{MeOH}=10 / 1\right)$ to give 22a as a colorless solid $\left(2.6 \mathrm{~g}, 92 \%\right.$ yield). mp $185-186{ }^{\circ} \mathrm{C} .{ }^{1} \mathrm{H}-\mathrm{NMR}\left(\mathrm{CDCl}_{3}\right) \delta$ : 1.64-1.77 (2H, dq, $J=4.1,12.2 \mathrm{~Hz}), 1.92-1.95$ (2H, m), 2.58$2.69(2 \mathrm{H}, \mathrm{m}), 2.92(1 \mathrm{H}, \mathrm{tt}, J=3.9,11.6 \mathrm{~Hz}), 3.00-3.09(2 \mathrm{H}, \mathrm{m})$, 7.06-7.15 (2H, m), $7.47(2 \mathrm{H}, \mathrm{m}), 12.11$ (1H, br s). LC/MS (ESI) $\mathrm{m} / \mathrm{z}: 336[\mathrm{M}+\mathrm{H}]^{+}$.

2-Piperidin-4-yl-1H-benzimidazole (22b) To a solution of $22 \mathrm{a}(2.5 \mathrm{~g}, 7.5 \mathrm{mmol})$ in $\mathrm{MeOH}(50 \mathrm{~mL})$ was added $10 \%$ palladium on carbon $(10 \mathrm{w} / \mathrm{w} \% ; 0.50 \mathrm{~g})$, and the mixture was stirred at room temperature under a hydrogen atmosphere for $4 \mathrm{~h}$. The catalyst was removed by filtration, and the filtrate was concentrated in vacuo to give $\mathbf{2 2} \mathbf{b}$ as a pale yellow solid (1.5 g, $99 \%$ yield). mp $259-265^{\circ} \mathrm{C} .{ }^{1} \mathrm{H}-\mathrm{NMR}$ (DMSO- $\left.d_{6}\right) \delta: 1.70(2 \mathrm{H}$, dq, $J=4.1,12.2 \mathrm{~Hz}), 1.92-1.95(2 \mathrm{H}, \mathrm{m}), 2.60-2.66(2 \mathrm{H}, \mathrm{m})$, $2.92(1 \mathrm{H}, \mathrm{tt}, J=3.9,11.6 \mathrm{~Hz}), 3.03-3.06(2 \mathrm{H}, \mathrm{m}), 7.09-7.12(2 \mathrm{H}$, m), 7.47 (2H, brs), $12.11(1 \mathrm{H}$, brs). LC/MS (ESI) $\mathrm{m} / \mathrm{z}: 202$ $[\mathrm{M}+\mathrm{H}]^{+}$.

2-[(2,3-Dihydro-1H-inden-5-yloxy)methyl]oxirane To a solution of 5-indanol (23) $(10.0 \mathrm{~g}, 74.5 \mathrm{mmol})$ in $\mathrm{N}, \mathrm{N}$ dimethylformamide (DMF) $(100 \mathrm{~mL})$ was added $60 \%$ sodium hydride in oil $(3.3 \mathrm{~g}, 82.0 \mathrm{mmol})$ at $0^{\circ} \mathrm{C}$. The mixture was stirred at $0^{\circ} \mathrm{C}$ for $30 \mathrm{~min}$, then at room temperature for $1 \mathrm{~h}$. To the resulting mixture was added epichlorohydrin $(6.5 \mathrm{~mL}$, $82.0 \mathrm{mmol})$ at $0^{\circ} \mathrm{C}$. After stirring overnight at room temperature, $1 \mathrm{M}$ aqueous $\mathrm{HCl}$ was added, and the whole was extracted with diethyl ether. The extract was washed with brine, dried over anhydrous $\mathrm{MgSO}_{4}$, and concentrated in vacuo. The residue was purified by column chromatography on silica gel (hexane/EtOAc $=20 / 1)$ to give 24 as a colorless oil $(10.3 \mathrm{~g}, 73 \%$ yield). ${ }^{1} \mathrm{H}-\mathrm{NMR}\left(\mathrm{CDCl}_{3}\right) \delta: 2.08(2 \mathrm{H}, \mathrm{q}, J=7.5 \mathrm{~Hz}), 2.74(1 \mathrm{H}$, $\mathrm{dd}, J=2.7,5.0 \mathrm{~Hz}), 2.81-2.91(5 \mathrm{H}, \mathrm{m}), 3.33-3.35(1 \mathrm{H}, \mathrm{m}), 3.95$ $(1 \mathrm{H}, \mathrm{dd}, J=5.4,11.1 \mathrm{~Hz}), 4.17(1 \mathrm{H}, \mathrm{dd}, J=3.3,11.1 \mathrm{~Hz}), 6.70$ $(1 \mathrm{H}, \mathrm{dd}, J=2.7,8.1 \mathrm{~Hz}), 6.80(1 \mathrm{H}, \mathrm{s}), 7.11(1 \mathrm{H}, \mathrm{d}, J=8.1 \mathrm{~Hz})$. LC/MS (ESI) $m / z: 191[\mathrm{M}+\mathrm{H}]^{+}$.

General Procedure for the Synthesis of 3-Amino-1-(5indanyloxy)-2-propanol Derivatives $(2 \mathrm{a}-\mathrm{g}, 3 \mathrm{a}-\mathrm{c}, 4 \mathrm{a}, \mathrm{b}) \mathrm{A}$ mixture of 24 and a corresponding piperidine $(\mathbf{8 c}, \mathbf{1 0 a}, \mathbf{c}, \mathbf{1 5 b}$, $16 \mathrm{~b}, 18 \mathrm{~b}, 20 \mathrm{~b}, \mathbf{2 2 b})$ or piperazine $(\mathbf{6}, 14 \mathrm{a}-\mathrm{c})$ in 2-propanol was heated to reflux with stirring for $3 \mathrm{~h}$. After cooling, $\mathrm{H}_{2} \mathrm{O}$ was added, and the whole was extracted with $\mathrm{CH}_{2} \mathrm{Cl}_{2}$. The extract was dried over anhydrous $\mathrm{MgSO}_{4}$ and concentrated in vacuo. The residual oil product was purified by column chromatography on silica gel $\left(\mathrm{CH}_{2} \mathrm{Cl}_{2} / \mathrm{MeOH}=30 / 1\right)$, or the crystalline product was washed with EtOAc. The obtained compounds were dissolved in EtOAc, and excess $4 \mathrm{~m} \mathrm{HCl-EtOAc} \mathrm{solution}$ was added. After stirring for $1 \mathrm{~h}$ at room temperature, the resulting precipitate was collected by filtration and washed with EtOAc to give the piperidine derivatives $(\mathbf{2} \mathbf{b}-\mathbf{d}, \mathbf{3 a}-\mathbf{c}$, or $\mathbf{4 a}, \mathbf{b})$ or piperazine derivatives (2a or $\mathbf{2} \mathbf{e}-\mathbf{g})$, respectively.

1-(2,3-Dihydro-1H-inden-5-yloxy)-3-[4-(4-phenoxyphenyl)piperazin-1-yl]propan-2-ol Hydrochloride (2a) This compound was obtained in $83 \%$ yield from $\mathbf{6}$ as a colorless solid. mp $163^{\circ} \mathrm{C} .{ }^{1} \mathrm{H}-\mathrm{NMR}$ (DMSO- $\left.d_{6}\right) \delta$ : $1.96-2.06(2 \mathrm{H}$, m), $2.78(2 \mathrm{H}, \mathrm{t}, J=7.5 \mathrm{~Hz}), 2.83(2 \mathrm{H}, \mathrm{t}, J=7.2 \mathrm{~Hz}), 3.02-3.20$ $(2 \mathrm{H}, \mathrm{m}), 3.22-3.32$ (4H, m), 3.58-3.82 (4H, m), 3.88-3.99 (2H, m), $4.39(1 \mathrm{H}$, brs $), 6.00(1 \mathrm{H}$, br s), $6.72(1 \mathrm{H}, \mathrm{dd}, J=2.6,8.2 \mathrm{~Hz})$, $6.85(1 \mathrm{H}, \mathrm{s}), 6.92(2 \mathrm{H}, \mathrm{dd}, J=1.0,8.7 \mathrm{~Hz}), 6.97-7.01(2 \mathrm{H}, \mathrm{m})$, $7.02-7.16(4 \mathrm{H}, \mathrm{m}), 7.31-7,39(2 \mathrm{H}, \mathrm{m}), 10.03$ (1H, brs). LC/ 
MS (ESI) $m / z: 445[\mathrm{M}+\mathrm{H}]^{+}$. IR [attenuated total reflectance (ATR) $\mathrm{cm}^{-1}:$ 3235, 2944, 1585, 1509, 1485, 1451, 1240, 869, 765, 519. Anal. Calcd for $\mathrm{C}_{28} \mathrm{H}_{32} \mathrm{~N}_{2} \mathrm{O}_{3} \cdot \mathrm{HCl} \cdot 0.5 \mathrm{H}_{2} \mathrm{O}$ : C, 68.63; H, 6.99; N, 5.72. Found: C, 68.48; H, 6.86; N, 5.66.

4-Biphenyl-4-yl-1-[3-(2,3-dihydro-1 H-inden-5-yloxy)-2hydroxypropyl]piperidin-4-ol Hydrochloride (2b) This compound was obtained in $76 \%$ yield from $8 \mathrm{c}$ as a colorless solid. mp $228^{\circ} \mathrm{C}$. ${ }^{1} \mathrm{H}-\mathrm{NMR}$ (DMSO- $\left.d_{6}\right) \delta$ : $1.85(2 \mathrm{H}, \mathrm{t}$, $J=15.4 \mathrm{~Hz}), 1.96-2.07$ (2H, m), 2.30-2.42 (2H, m), 2.74-2.88 (4H, m), 3.27-3.45 (4H, m), 3.48-3.61 (2H, m), 3.89-4.02 (2H, m), 4.31-4.45 (1H, m), $5.54(1 \mathrm{H}, \mathrm{s}), 5.96(1 \mathrm{H}, \mathrm{d}, J=5.1 \mathrm{~Hz})$, 6.69-6.77 (1H, m), $6.86(1 \mathrm{H}, \mathrm{s}), 7.13(1 \mathrm{H}, \mathrm{d}, J=8.2 \mathrm{~Hz})$, $7.37(1 \mathrm{H}, \mathrm{t}, J=8.2 \mathrm{~Hz}), 7.47(2 \mathrm{H}, \mathrm{t}, J=7.7 \mathrm{~Hz}), 7.56(2 \mathrm{H}, \mathrm{d}$, $J=8.2 \mathrm{~Hz}), 7.68(4 \mathrm{H}, \mathrm{m}), 9.63(1 \mathrm{H}, \mathrm{brs}) . \mathrm{LC} / \mathrm{MS}(\mathrm{ESI}) \mathrm{m} / \mathrm{z}: 444$ $[\mathrm{M}+\mathrm{H}]^{+}$. IR (ATR) $\mathrm{cm}^{-1}:$ 3312, 3179, 2924, 1604, 1488, 1473, 1049, 763, 635. Anal. Calcd for $\mathrm{C}_{29} \mathrm{H}_{33} \mathrm{NO}_{3} \cdot \mathrm{HCl}: \mathrm{C}, 72.56 ; \mathrm{H}$, 7.14; N, 2.92. Found: C, 72.36; H, 7.12; N, 2.89.

1-(4-Biphenyl-4-ylpiperidin-1-yl)-3-(2,3-dihydro-1 Hinden-5-yloxy)propan-2-ol Hydrochloride (2c) This compound was obtained in $79 \%$ yield from 10a as a colorless solid. mp $243^{\circ} \mathrm{C}$. ${ }^{1} \mathrm{H}-\mathrm{NMR}$ (DMSO- $\left.d_{6}\right) \delta: 1.94-2.20(6 \mathrm{H}, \mathrm{m})$, 2.74-2.94 (5H, m), 3.05-3.24 (4H, m), 3.62-3.73 (2H, m), 3.89$3.99(2 \mathrm{H}, \mathrm{m}), 4.31-4.42(1 \mathrm{H}, \mathrm{m}), 5.95(1 \mathrm{H}, \mathrm{d}, J=5.1 \mathrm{~Hz}), 6.73$ $(1 \mathrm{H}, \mathrm{dd}, J=2.3,8.0 \mathrm{~Hz}), 6.86(1 \mathrm{H}, \mathrm{d}, J=2.1 \mathrm{~Hz}), 7.13(1 \mathrm{H}, \mathrm{d}$, $J=8.2 \mathrm{~Hz}), 7.31-7.39(3 \mathrm{H}, \mathrm{m}), 7.46$ (2H, t, $J=8.2 \mathrm{~Hz}), 7.61-7.69$ $(4 \mathrm{H}, \mathrm{m}), 9.60(1 \mathrm{H}, \mathrm{brs})$. LC/MS (ESI) $m / z: 428[\mathrm{M}+\mathrm{H}]^{+}$. IR (ATR) $\mathrm{cm}^{-1}$ : 3278, 2939, 1604, 1483, 1251, 1045, 832, 760, 693. Anal. Calcd for $\mathrm{C}_{29} \mathrm{H}_{33} \mathrm{NO}_{2} \cdot \mathrm{HCl} \cdot 0.1 \mathrm{H}_{2} \mathrm{O}: \mathrm{C}, 74.77 ; \mathrm{H}$, 7.40; N, 3.01. Found: C, 74.62; H, 7.24; N, 2.98.

1-(2,3-Dihydro-1H-inden-5-yloxy)-3-[4-(4-pyridin-3ylphenyl)piperidin-1-yl]propan-2-ol Dihydrochloride (2d) This compound was obtained in $21 \%$ yield from $10 \mathrm{c}$ as a colorless solid. mp $216^{\circ} \mathrm{C}$. ${ }^{1} \mathrm{H}-\mathrm{NMR}$ (DMSO- $d_{6}$ ) $\delta$ : 1.95-2.22 $(6 \mathrm{H}, \mathrm{m}), 2.78(2 \mathrm{H}, \mathrm{t}, J=7.2 \mathrm{~Hz}), 2.83(2 \mathrm{H}, \mathrm{t}, J=7.5 \mathrm{~Hz})$, 2.88-2.98 (1H, m), 3.25 (4H, m), 3.63-3.74 (2H, m), 3.90-4.01 $(2 \mathrm{H}, \mathrm{m}), 4.34-4.44(1 \mathrm{H}, \mathrm{m}), 6.69-6.77(1 \mathrm{H}, \mathrm{m}), 6.86(1 \mathrm{H}, \mathrm{s})$, $7.13(1 \mathrm{H}, \mathrm{d}, J=8.2 \mathrm{~Hz}), 7.42(2 \mathrm{H}, \mathrm{d}, J=8.2 \mathrm{~Hz}), 7.70-7.83(3 \mathrm{H}$, m), 8.33-8.43 (1H, m), $8.69(1 \mathrm{H}, \mathrm{d}, J=4.6 \mathrm{~Hz}), 9.03(1 \mathrm{H}, \mathrm{s})$, $9.66\left(1 \mathrm{H}\right.$, br s). LC/MS (ESI) $m / z: 429[\mathrm{M}+\mathrm{H}]^{+}$. IR (ATR) $\mathrm{cm}^{-1}$ : 3281, 2918, 2662, 1473, 1044, 808. Anal. Calcd for $\mathrm{C}_{28} \mathrm{H}_{32} \mathrm{~N}_{2} \mathrm{O}_{2} \cdot 2 \mathrm{HCl} \cdot 1.5 \mathrm{H}_{2} \mathrm{O}: \mathrm{C}, 63.63 ; \mathrm{H}, 7.06 ; \mathrm{N}, 5.30$. Found: C, 63.28; H, 7.01; N, 5.24.

1-(2,3 - Dihydro-1H-inden-5-yloxy)-3 - [4 - (5 - phenylpyridin-2-yl)piperazin-1-yl]propan-2-ol Dihydrochloride (2e) This compound was obtained in $46 \%$ yield from 14a as a colorless solid. mp $237^{\circ} \mathrm{C} .{ }^{1} \mathrm{H}-\mathrm{NMR}\left(\mathrm{DMSO}-d_{6}\right) \delta: 1.95-2.06$ $(2 \mathrm{H}, \mathrm{m}), 2.78(2 \mathrm{H}, \mathrm{t}, J=7.2 \mathrm{~Hz}), 2.83(2 \mathrm{H}, \mathrm{t}, J=7.5 \mathrm{~Hz}), 3.10$ 3.43 (6H, m), 3.60-3.71 (2H, m), 3.89-3.99 (2H, m), 4.32-4.52 $(3 \mathrm{H}, \mathrm{m}), 6.72(1 \mathrm{H}, \mathrm{dd}, J=2.6,8.2 \mathrm{~Hz}), 6.84(1 \mathrm{H}, \mathrm{s}), 7.08(1 \mathrm{H}$, $\mathrm{d}, J=8.7 \mathrm{~Hz}), 7.12(1 \mathrm{H}, \mathrm{d}, J=8.2 \mathrm{~Hz}), 7.31-7.38(1 \mathrm{H}, \mathrm{m}), 7.45$ $(2 \mathrm{H}, \mathrm{t}, J=7.7 \mathrm{~Hz}), 7.65(2 \mathrm{H}, \mathrm{d}, J=7.2 \mathrm{~Hz}), 7.95-8.02(1 \mathrm{H}, \mathrm{m})$, $8.50(1 \mathrm{H}, \mathrm{d}, J=2.1 \mathrm{~Hz}), 10.03(1 \mathrm{H}, \mathrm{brs}) . \mathrm{LC} / \mathrm{MS}$ (ESI) $\mathrm{m} / \mathrm{z}: 430$ $[\mathrm{M}+\mathrm{H}]^{+}$. IR (ATR) $\mathrm{cm}^{-1}: 3682,3325,2952,2844,2722,1649$, 1616, 1492, 1440, 1277, 1244, 1055, 1033, 990, 797, 757, 693. Anal. Calcd for $\mathrm{C}_{27} \mathrm{H}_{31} \mathrm{~N}_{3} \mathrm{O}_{2} \cdot 2 \mathrm{HCl} \cdot 0.5 \mathrm{H}_{2} \mathrm{O}: \mathrm{C}, 63.40 ; \mathrm{H}, 6.70$; N, 8.22. Found: C, 63.66; H, 6.47; N, 8.20.

1 - ( 2,3 - D i h y d r o - $1 H$ - ind e n - 5 - y lox y ) - 3 - [ 4 - ( 6 phenylpyridazin-3-yl)piperazin-1-yl]propan-2-ol Hydrochloride (2f) This compound was obtained in $37 \%$ yield from $\mathbf{1 4 b}$ as a colorless solid. mp $229^{\circ} \mathrm{C}$. ${ }^{1} \mathrm{H}-\mathrm{NMR}$ $\left(\mathrm{DMSO}_{6}\right) \delta$ : 1.95-2.05 (2H, m), $2.80(4 \mathrm{H}, \mathrm{dt}, J=7.3,19.4 \mathrm{~Hz})$,
3.19-3.30 (4H, m), 3.42-3.57 (2H, m), 3.63-3.74 (2H, m), 3.89-4.00 (2H, m), 4.33-4.43 (1H, m), 4.47-4.63 (2H, m), 6.72 $(1 \mathrm{H}, \mathrm{dd}, J=2.3,8.5 \mathrm{~Hz}), 6.84(1 \mathrm{H}, \mathrm{s}), 7.12(1 \mathrm{H}, \mathrm{d}, J=8.2 \mathrm{~Hz})$, 7.41-7.56 (4H, m), 8.01-8.12 (3H, m), 10.06 (1H, brs). LC/MS (ESI) $m / z: 431[\mathrm{M}+\mathrm{H}]^{+}$. IR (ATR) $\mathrm{cm}^{-1}: 3306,2937,2578$, 1642, 1592, 1579, 1548, 1481, 1462, 1442, 1419, 1239, 1055, 1033, 779, 690. Anal. Calcd for $\mathrm{C}_{26} \mathrm{H}_{30} \mathrm{~N}_{4} \mathrm{O}_{2} \cdot \mathrm{HCl} \cdot 0.5 \mathrm{H}_{2} \mathrm{O}: \mathrm{C}$, 65.60; H, 6.78; N, 11.77. Found: C, 65.36; H, 6.47; N, 11.67.

1-(2,3-Dihydro-1H-inden-5-yloxy)-3-[4-(4-pyridin-3ylphenyl)piperazin-1-yl]propan-2-ol Dihydrochloride (2g) This compound was obtained in $75 \%$ yield from $14 \mathrm{c}$ as a yellow solid. mp $199^{\circ} \mathrm{C}$. ${ }^{1} \mathrm{H}-\mathrm{NMR}\left(\mathrm{DMSO}-d_{6}\right) \delta$ : $1.95-2.06$ (2H, m), 2.80 (4H, dt, $J=7.3,19.8 \mathrm{~Hz}), 3.22$ (4H, m), 3.61-3.74 $(4 \mathrm{H}, \mathrm{m}), 3.88-4.05(4 \mathrm{H}, \mathrm{m}), 4.34-4.44(1 \mathrm{H}, \mathrm{m}), 6.72(1 \mathrm{H}, \mathrm{dd}$, $J=2.6,8.2 \mathrm{~Hz}), 6.85(1 \mathrm{H}, \mathrm{s}), 7.13(1 \mathrm{H}, \mathrm{d}, J=8.2 \mathrm{~Hz}), 7.17(2 \mathrm{H}$, d, $J=8.7 \mathrm{~Hz}), 7.71-7.83(3 \mathrm{H}, \mathrm{m}), 8.42-8.51(1 \mathrm{H}, \mathrm{m}), 8.65(1 \mathrm{H}$, d, $J=5.1 \mathrm{~Hz}), 9.05(1 \mathrm{H}, \mathrm{s}), 10.10(1 \mathrm{H}, \mathrm{brs})$. LC/MS (ESI) $\mathrm{m} / \mathrm{z}$ : $430[\mathrm{M}+\mathrm{H}]^{+}$. IR (ATR) $\mathrm{cm}^{-1}:$ 3269, 2968, 2596, 1607, 1522, 1471, 1258, 1241, 1044, 1034, 799, 678, 618. Anal. Calcd for $\mathrm{C}_{27} \mathrm{H}_{31} \mathrm{~N}_{3} \mathrm{O}_{2} \cdot 2 \mathrm{HCl} \cdot 2 \mathrm{H}_{2} \mathrm{O}: \mathrm{C}, 60.22 ; \mathrm{H}, 6.93 ; \mathrm{N}, 7.80$. Found: C, $60.34 ; \mathrm{H}, 6.70 ; \mathrm{N}, 7.73$.

1-(2,3-Dihydro-1 $H$-inden-5-yloxy)-3-(1'H,3H-spiro[2benzofuran-1,4'-piperidin]-1'-yl)propan-2-ol Hydrochloride (3a) This compound was obtained in $85 \%$ yield from $\mathbf{1 5 b}$ as a colorless solid. mp $207^{\circ} \mathrm{C} .{ }^{1} \mathrm{H}-\mathrm{NMR}\left(\mathrm{DMSO}-d_{6}\right) \delta: 1.85$ $(2 \mathrm{H}, \mathrm{t}, J=15.7 \mathrm{~Hz}), 2.01(2 \mathrm{H}, \mathrm{m}), 2.22-2.46(2 \mathrm{H}, \mathrm{m}), 2.81(4 \mathrm{H}$, $\mathrm{dt}, J=7.6,19.8 \mathrm{~Hz}), 3.19-3.38(4 \mathrm{H}, \mathrm{m}), 3.55-3.65(2 \mathrm{H}, \mathrm{m})$, 3.88-4.02 (2H, m), 4.32-4.42 (1H, m), $5.06(2 \mathrm{H}, \mathrm{s}), 5.96(1 \mathrm{H}$, $\mathrm{d}, J=8.2 \mathrm{~Hz}), 6.73(1 \mathrm{H}, \mathrm{d}, J=8.2 \mathrm{~Hz}), 6.85(1 \mathrm{H}, \mathrm{s}), 7.09-7.20$ (2H, m), 7.30-7.39 (3H, m), 9.73 (1H, br s). LC/MS (ESI) $m / z$ : $380[\mathrm{M}+\mathrm{H}]^{+}$. IR (ATR) $\mathrm{cm}^{-1}:$ 3681, 3215, 2937, 2844, 1606, 1494, 1475, 1252, 1046, 1038, 1017, 833, 749. Anal. Calcd for $\mathrm{C}_{24} \mathrm{H}_{29} \mathrm{NO}_{3} \cdot \mathrm{HCl}: \mathrm{C}, 69.30 ; \mathrm{H}, 7.27 ; \mathrm{N}, 3.37$. Found: C, 68.97; $\mathrm{H}, 7.16$; N, 3.32.

1-(2,3 - Dihydro- $1 H$-inden-5-yloxy)-3-(3-phenyl-1oxa-2,4,8-triazaspiro[4,5]dec-2-en-8-yl)propan-2-ol Hydrochloride (3b) This compound was obtained in $87 \%$ yield from $\mathbf{1 6 b}$ as a colorless solid. mp $241{ }^{\circ} \mathrm{C} .{ }^{1} \mathrm{H}-\mathrm{NMR}$ $\left(\mathrm{DMSO}-d_{6}\right) \delta: 1.99-2.15(6 \mathrm{H}, \mathrm{m}), 2.80(4 \mathrm{H}, \mathrm{dt}, J=7.5,19.5 \mathrm{~Hz})$, 3.17-3.40 (4H, m), $3.62(2 \mathrm{H}, \mathrm{m}), 3.87-3.99(2 \mathrm{H}, \mathrm{m}), 4.31(1 \mathrm{H}$, m), $6.00(1 \mathrm{H}, \mathrm{m}), 6.72(1 \mathrm{H}, \mathrm{d}, J=8.7 \mathrm{~Hz}), 6.85(1 \mathrm{H}, \mathrm{s}), 7.13(1 \mathrm{H}$, d, $J=8.2 \mathrm{~Hz}), 7.48-7.52(3 \mathrm{H}, \mathrm{m}), 7.68(2 \mathrm{H}, \mathrm{d}, J=7.7 \mathrm{~Hz}), 7.84$ $(1 \mathrm{H}, \mathrm{m}), 9.53\left(1 \mathrm{H}\right.$, brs). LC/MS (ESI) $\mathrm{m} / \mathrm{z}: 408[\mathrm{M}+\mathrm{H}]^{+}$. IR (ATR) $\mathrm{cm}^{-1}:$ 3682, 3234, 2938, 2667, 1607, 1513, 1461, 1433, 1051, 1033, 839, 770, 692. Anal. Calcd for $\mathrm{C}_{24} \mathrm{H}_{29} \mathrm{~N}_{3} \mathrm{O}_{3} \cdot \mathrm{HCl}: \mathrm{C}$, 64.93; H, 6.81; N, 9.46. Found: C, 64.71; H, 6.44; N, 9.36.

1-(2,3-Dihydro-1H-inden-5-yloxy)-3-(1,2-dihydro$1^{\prime} H$-spiro[indole-3, $4^{\prime}$-piperidin]-1'-yl)propan-2-ol Hydrochloride (3c) This compound was obtained in 53\% yield from $18 \mathbf{b}$ as a colorless solid. mp $250{ }^{\circ} \mathrm{C} .{ }^{1} \mathrm{H}-\mathrm{NMR}$ $\left(\mathrm{DMSO}_{6}\right) \delta$ : 1.74-1.83 (2H, m), 1.97-2.12 (3H, m), 2.18-2.24 $(1 \mathrm{H}, \mathrm{m}), 2.80(4 \mathrm{H}, \mathrm{dt}, J=7.3,19.8 \mathrm{~Hz}), 3.06-3.38(6 \mathrm{H}, \mathrm{m})$, $3.55(2 \mathrm{H}, \mathrm{m}), 3.88-4.00(2 \mathrm{H}, \mathrm{m}), 4.33(1 \mathrm{H}, \mathrm{m}), 5.66(1 \mathrm{H}, \mathrm{brs})$, $5.97(1 \mathrm{H}, \mathrm{d}, J=4.6 \mathrm{~Hz}), 6.51(1 \mathrm{H}, \mathrm{d}, J=7.7 \mathrm{~Hz}), 6.60(1 \mathrm{H}, \mathrm{t}$, $J=7.2 \mathrm{~Hz}), 6.71-6.73(1 \mathrm{H}, \mathrm{m}), 6.85(1 \mathrm{H}, \mathrm{s}), 6.91-6.98(2 \mathrm{H}, \mathrm{m})$, $7.13(1 \mathrm{H}, \mathrm{d}, J=8.2 \mathrm{~Hz}), 9.42(1 \mathrm{H}, \mathrm{brs})$. LC/MS (ESI) $\mathrm{m} / \mathrm{z}: 379$ $[\mathrm{M}+\mathrm{H}]^{+}$. IR (ATR) $\mathrm{cm}^{-1}:$ 3244, 2961, 2837, 2693, 1606, 1486, 1463, 1251, 1048, 1033, 830, 734. Anal. Calcd for $\mathrm{C}_{24} \mathrm{H}_{30} \mathrm{~N}_{2} \mathrm{O}_{2}$ $\cdot \mathrm{HCl} \cdot 0.2 \mathrm{H}_{2} \mathrm{O}$ : C, 68.87; H, 7.56; N, 6.69. Found: C, 68.55; H, $7.17 ; \mathrm{N}, 6.65$.

1-(2,3-Dihydro-1 $H$-inden-5-yloxy)-3-[4-(3-phenyl-1,2,4- 
oxadiazol-5-yl)piperidin-1-yl]propan-2-ol Hydrochloride (4a) This compound was obtained in $35 \%$ yield from 20 b as a colorless solid. mp $202^{\circ} \mathrm{C} .{ }^{1} \mathrm{H}-\mathrm{NMR}$ (DMSO- $d_{6}$ ) $\delta: 1.97-2.29$ $(4 \mathrm{H}, \mathrm{m}), 2.35-2.43(2 \mathrm{H}, \mathrm{m}), 2.80(4 \mathrm{H}, \mathrm{dt}, J=7.1,20.0 \mathrm{~Hz})$, 3.15-3.30 (4H, m), 3.63-3.77 (2H, m), 3.91-3.99 (2H, m), 4.33 $(1 \mathrm{H}, \mathrm{m}), 5.98(1 \mathrm{H}, \mathrm{d}, J=4.6 \mathrm{~Hz}), 6.71-6.73(1 \mathrm{H}, \mathrm{m}), 6.82-6.85$ $(1 \mathrm{H}, \mathrm{m}), 7.10-7.14(1 \mathrm{H}, \mathrm{m}), 7.57-7.63(3 \mathrm{H}, \mathrm{m}), 8.00-8.08(2 \mathrm{H}$, m), 9.58 (1H, brs). LC/MS (ESI) $m / z: 420[\mathrm{M}+\mathrm{H}]^{+}$. IR (ATR) $\mathrm{cm}^{-1}:$ 3682, 3257, 2967, 2845, 2519, 1570, 1493, 1474, 1447, 1047, 1033, 1015, 695. Anal. Calcd for $\mathrm{C}_{25} \mathrm{H}_{29} \mathrm{~N}_{3} \mathrm{O}_{3} \cdot \mathrm{HCl}: \mathrm{C}$, 65.85; H, 6.63; N, 9.22. Found: C, 65.95; H, 6.48; N, 9.18.

1-[4-(1H-Benzimidazol-2-yl)piperidin-1-yl]-3-(2,3-dihydro-1 $H$-inden-5-yloxy)propan-2-ol Dihydrochloride (4b) This compound was obtained in $54 \%$ yield from $\mathbf{2 2 b}$ as a colorless solid. mp $264^{\circ} \mathrm{C}$. ${ }^{1} \mathrm{H}-\mathrm{NMR}$ (DMSO- $d_{6}$ ) $\delta$ : $1.97-2.03$ (2H, m), $2.41(4 \mathrm{H}, \mathrm{m}), 2.81(4 \mathrm{H}, \mathrm{dt}, J=7.2,19.8 \mathrm{~Hz}), 3.15-3.30$ (4H, m), 3.68-3.80 (2H, m), 3.87-4.01 (2H, m), $4.39(1 \mathrm{H}, \mathrm{m})$, $5.99(1 \mathrm{H}$, brs $), 6.73(1 \mathrm{H}, \mathrm{d}, J=8.7 \mathrm{~Hz}), 6.83-6.86(1 \mathrm{H}, \mathrm{m})$, 7.08-7.14 (1H, m), 7.43 (2H, m), 7.72 (2H, m), 9.58 (1H, brs). LC/MS (ESI) m/z: $392[\mathrm{M}+\mathrm{H}]^{+}$. IR (ATR) $\mathrm{cm}^{-1}: 3681,2939$, 2844, 2725, 1608, 1491, 1461, 1054, 1033, 1017, 819, 742. Anal. Calcd for $\mathrm{C}_{24} \mathrm{H}_{29} \mathrm{~N}_{3} \mathrm{O}_{2} \cdot 2 \mathrm{HCl} \cdot 0.5 \mathrm{H}_{2} \mathrm{O}: \mathrm{C}, 60.89 ; \mathrm{H}, 6.81 ; \mathrm{N}$, 8.88. Found: C, 60.74; H, 6.67; N, 8.79.

Inhibitory Effect on Veratridine-Induced $\mathrm{Na}^{+}$Channel Depolarization The membrane potential of synaptosomes was measured according to the procedure of Aiuchi et al. ${ }^{32)}$ The standard medium consisted of $132 \mathrm{~mm} \mathrm{NaCl}, 5 \mathrm{~mm} \mathrm{KCl}$, $20 \mathrm{~mm}$ Tris- $\mathrm{HCl}$ ( $\mathrm{pH} 7.4$ ), and $10 \mathrm{~mm}$ glucose. Synaptosomes were prepared from rat brain membranes (male Wister rats, 7-15 weeks old). Fluorescence was measured with a spectrofluorometer (an excitation wavelength of $520 \mathrm{~nm}$ and an emission wavelength of $550 \mathrm{~nm}$ ). Rhodamine $6 \mathrm{G}$, each test compound, and veratridine were added to $1 \mathrm{~mL}$ of the standard medium in a fluorometer cuvette, and the initial fluorescence, $f_{\mathrm{i}}$, was measured. Then, $50 \mu \mathrm{L}$ of synaptosomes suspension was added to the cuvette, and the fluorescence in the steady state, $f_{\mathrm{s}}$, was measured. The fluorescence, $f$, was defined as $f=\left(f_{\mathrm{s}} / f_{\mathrm{i}}\right)$.

Binding Affinity for Dopamine $\mathrm{D}_{\mathbf{2}}$ Receptors A membrane fraction prepared from the striatum of female Lewis rats $(450 \mu \mathrm{L})$ was incubated with each test compound and $0.2 \mathrm{nM}$ $\left[{ }^{3} \mathrm{H}\right]$-spiperone in a buffer solution $(50 \mathrm{~mm}$ Tris- $\mathrm{HCl}, 120 \mathrm{~mm}$ $\mathrm{NaCl}, 5 \mathrm{~mm} \mathrm{KCl}, 2 \mathrm{mM} \mathrm{CaCl}_{2}$, and $1 \mathrm{mM} \mathrm{MgCl}_{2}, \mathrm{pH} \mathrm{7.4)} \mathrm{at}$ $37^{\circ} \mathrm{C}$ for $20 \mathrm{~min}$. Bound radioactivity was counted after rapid vacuum filtration through a $\mathrm{GF} / \mathrm{B}$ glass filter. Nonspecific binding was determined using $100 \mu \mathrm{M}(-)$-sulpiride.

Effect of Compound 4b on Ischemic Brain Damage in a Rat Transient Middle Cerebral Artery (MCA) Occlusion Model Wister rats (male, 8 weeks old) were anesthetized with halothane. They were then subjected to transient MCA occlusion for $90 \mathrm{~min}$ according to the modified method of Koizumi et al., ${ }^{35)}$ followed by reperfusion. Compound $\mathbf{4 b}$ was administered intraperitoneally immediately after both occlusion and reperfusion at a dose of $30 \mathrm{mg} / \mathrm{kg}$ (salt form) each time. Control rats that also underwent transient MCA occlusion received an equal volume of saline at the corresponding time points. The brains were dissected into 7 slices $24 \mathrm{~h}$ after the occlusion and stained with TTC. ${ }^{36)}$ The area of infarct tissue for each slice was determined with a computerized image analysis system, and the infarct volume was calculated.

Binding Affinity for $\left[{ }^{3} \mathbf{H}\right]-$ BTX $\left[{ }^{3} \mathrm{H}\right]$-Batrachotoxin-A-
20- $\alpha$-benzoate (BTX-b) was purchased from PerkinElmer. $\left[{ }^{3} \mathrm{H}\right]-\mathrm{BTX}-\mathrm{b}$ binding was measured in synaptosomal preparations of rat cerebral cortex using a modified procedure previously described. ${ }^{11)}$ The standard binding medium consisted of $130 \mathrm{~mm}$ chlorine chloride, $50 \mathrm{~mm}$ 4-(2-hydroxyethyl)-1-piperazineethanesulfonic acid (adjusted to $\mathrm{pH} 7.4$ at $36^{\circ} \mathrm{C}$ with Tris base), $5.5 \mathrm{~mm}$ glucose, $0.8 \mathrm{~mm} \mathrm{MgSO}_{4}, 5.4 \mathrm{~mm} \mathrm{KCl}, 1 \mathrm{mg} / \mathrm{mL}$ of bovine serum albumin. Binding reactions were initiated by addition of synaptosomes suspended in $100 \mu \mathrm{M}$ of the standard binding medium to a reaction mixture containing $10 \mathrm{~nm}\left[{ }^{3} \mathrm{H}\right]-$ BTX, $300 \mu \mathrm{m}$ veratridine, and $30 \mu \mathrm{g} / \mathrm{mL}$ of scorpion toxin in $150 \mu \mathrm{M}$ of the standard binding medium. Compound $4 \mathrm{~b}$ was mixed and incubated for $1 \mathrm{~h}$ at $37^{\circ} \mathrm{C}$. The reactions were stopped by addition of $3 \mathrm{~mL}$ of ice-cold wash medium consisting of $163 \mathrm{~mm}$ chlorine chloride, $5 \mathrm{~mm} 4$-(2-hydroxyethyl)-1-piperazineethanesulfonic acid (adjusted to $\mathrm{pH} 7.4$ at $36^{\circ} \mathrm{C}$ with Tris base), $1.8 \mathrm{~mm} \mathrm{CaCl}_{2}, 0.8 \mathrm{~mm} \mathrm{MgSO}_{4}, 1 \mathrm{mg} / \mathrm{mL}$ of bovine serum albumin. The synaptosomes were immediately collected on GF/C glass filters under vacuum and washed 3 times with $3 \mathrm{~mL}$ of the wash medium. The filters were suspended in liquid scintillation fluid, and bound radioactivity was counted in a liquid scintillation spectrometer.

In Vitro Metabolic Stability in Rat Liver Microsomes To a $0.1 \mathrm{M}$ potassium phosphate buffer $(\mathrm{pH}$ 7.4) containing a test compound $(1 \mu \mathrm{M}), 0.25 \mathrm{mg} / \mathrm{mL}$ of male rat liver microsomes, and $5 \mathrm{~mm} \mathrm{MgCl}_{2}, 1 \mathrm{~mm}$ reduced nicotinamide adenine dinucleotide phosphate (NADPH) was added to start a reaction. After incubation for 0,5 , or $10 \mathrm{~min}$ at $37^{\circ} \mathrm{C}, \mathrm{CH}_{3} \mathrm{CN}$ was added to stop the reaction. The concentration of the test compound at each time point was measured by LC/MS. Hepatic intrinsic clearance (CL) was determined by the temporal changes in the concentration of the test compound.

\section{References}

1) Simon R. P., Swan J. H., Griffiths T., Meldrum B. S., Science, 226 , $850-852$ (1984).

2) Park C. K., Nehls D. G., Graham D. I., Teasdale G. M., McCulloch J., Ann. Neurol., 24, 543-551 (1988).

3) Carter C. J., Lloyd K. G., Zivkovic B., Scatton B., J. Pharmacol. Exp. Ther., 253, 475-482 (1990).

4) Sheardown M. J., Nielsen E. O., Hansen A. J., Jacobsen P., Honoré T., Science, 247, 571-574 (1990).

5) Takahashi M., Kohara A., Shishikura J., Kawasaki-Yatsugi S., Ni J. W., Yatsugi S., Sakamoto S., Okada M., Shimizu-Sasamata M., Yamaguchi T., CNS Drug Rev., 8, 337-352 (2002).

6) Zornow M. H., Prough D. S., New Horiz., 4, 107-114 (1996).

7) Taylor C. P., Meldrum B. S., Trends Pharmacol. Sci., 16, 309-316 (1995).

8) Urenjak J., Obrenovitch T. P., Pharmacol. Rev., 48, 21-67 (1996).

9) Hodgkin A. L., Huxley A. F., J. Physiol., 117, 500-544 (1952).

10) Catterall W. A., J. Biol. Chem., 252, 8669-8676 (1977).

11) Catterall W. A., Morrow C. S., Daly J. W., Brown G. B., J. Biol. Chem., 256, 8922-8927 (1981).

12) Albuquerque E. X., Daly J. W., Witkop B., Science, 172, 995-1002 (1971).

13) Catterall W. A., Annu. Rev. Pharmacol. Toxicol., 20, 15-43 (1980).

14) Deri Z., Adam-Vizi V., J. Neurochem., 61, 818-825 (1993).

15) Willow M., Catterall W. A., Mol. Pharmacol., 22, 627-635 (1982).

16) Matsuki N., Quandt F. N., Ten Eick R. E., Yeh J. Z., J. Pharmacol. Exp. Ther., 228, 523-530 (1984).

17) Kuo C. C., Bean B. P., Mol. Pharmacol., 46, 716-725 (1994).

18) Hille B., J. Gen. Physiol., 69, 497-515 (1977).

19) Löscher W., Wlaź P., Szabo L., Neurosci. Lett., 240, 33-36 (1998). 
20) Shimidzu T., Itou Y., Tatsumi S., Hayashi S., Ukai Y., Yoshikuni Y., Kimura K., Naunyn Schmiedebergs Arch. Pharmacol., 355, 601-608 (1997).

21) Carter A. J., Grauert M., Pschorn U., Bechtel W. D., BartmannLindholm C., Qu Y., Scheuer T., Catterall W. A., Weiser T., Proc. Natl. Acad. Sci. U.S.A., 97, 4944-4949 (2000).

22) Kotani Y., Morimoto N., Oida Y., Tamura Y., Tamura S., Inoue T., Shimazawa M., Yoshimura S., Iwama T., Hara H., Neuroscience, 149, 779-788 (2007)

23) Annoura H., Nakanishi K., Toba T., Takemoto N., Imajo S., Miyajima A., Tamura-Horikawa Y., Tamura S., J. Med. Chem., 43, 3372-3376 (2000).

24) Montastruc J. L., Llau M. E., Rascol O., Senard J. M., Fundam. Clin. Pharmacol., 8, 293-306 (1994).

25) Annoura H., Nakanishi K., Uesugi M., Fukunaga A., Imajo S., Miyajima A., Tamura-Horikawa Y., Tamura S., Bioorg. Med. Chem., 10, 371-383 (2002)

26) Miyaura N., Suzuki A., Chem. Rev., 95, 2457-2483 (1995).

27) Suzuki A., J. Organomet. Chem., 576, 147-168 (1999).
28) Kubota H., Fujii M., Ikeda K., Takeuchi M., Shibanuma T., Isomura Y., Chem. Pharm. Bull., 46, 351-354 (1998).

29) Wovkulich P. M., Uskoković M. R., Tetrahedron, 41, 3455-3462 (1985).

30) Liang G. B., Qian X., Bioorg. Med. Chem. Lett., 9, 2101-2104 (1999).

31) Kelarev V. I., Shvekhgeimer G. A., Chem. Heterocycl. Compd., 16, 501-506 (1980).

32) Aiuchi T., Daimatsu T., Nakaya K., Nakamura Y., Biochim. Biophys. Acta, 685, 289-296 (1982).

33) Zhang A., Neumeyer J. L., Baldessarini R. J., Chem. Rev., 107, 274-302 (2007).

34) van de Waterbeemd H., Camenisch G., Folkers G., Chretien J. R., Raevsky O. A., J. Drug Target., 6, 151-165 (1998).

35) Koizumi J., Yoshida Y., Nakazawa T., Ooneda G., Jpn. J. Stroke, 8, 1-8 (1986).

36) Bederson J. B., Pitts L. H., Germano S. M., Nishimura M. C., Davis R. L., Bartkowski H. M., Stroke, 17, 1304-1308 (1986). 